NBER WORKING PAPER SERIES

\title{
THE HOMECOMING OF AMERICAN COLLEGE WOMEN: THE REVERSAL OF THE COLLEGE GENDER GAP
}

\author{
Claudia Goldin \\ Lawrence F. Katz \\ Ilyana Kuziemko \\ Working Paper 12139 \\ http://www.nber.org/papers/w12139
NATIONAL BUREAU OF ECONOMIC RESEARCH
1050 Massachusetts Avenue
Cambridge, MA 02138
March 2006

\begin{abstract}
We are grateful to the seminar participants at Harvard University, the University of Minnesota, Carnegie Mellon University, Princeton University, Columbia University, and the University of California at Davis. We thank James Hines, Brian Jacob, Sam Peltzman, Andrei Shleifer, and Michael Waldman for their detailed and helpful comments. Goldin and Katz are grateful to the Andrew W. Mellon Foundation and the Radcliffe Institute for Advanced Study for research support. The views expressed herein are those of the author(s) and do not necessarily reflect the views of the National Bureau of Economic Research.

(C2006 by Claudia Goldin, Lawrence F. Katz and Ilyana Kuziemko. All rights reserved. Short sections of text, not to exceed two paragraphs, may be quoted without explicit permission provided that full credit, including () notice, is given to the source.
\end{abstract}


The Homecoming of American College Women: The Reversal of the College Gender Gap Claudia Goldin, Lawrence F. Katz and Ilyana Kuziemko

NBER Working Paper No. 12139

March 2006

JEL No. I2, J1, J2, N3

\begin{abstract}
$\underline{\text { ABSTRACT }}$
Women are currently the majority of U.S. college students and of those receiving a bachelor's degree, but were 39 percent of undergraduates in 1960. We use three longitudinal data sets of high school graduates in 1957, 1972, and 1992 to understand the narrowing of the gender gap in college and its reversal. From 1972 to 1992 high school girls narrowed the gap with boys in math and science course taking and in achievement test scores. These variables, which we term the proximate determinants, can account for 30 to 60 percent of the relative increase in women's college completion rate. Behind these changes were several others: the future work expectations of young women increased greatly between 1968 and 1979 and the age at first marriage for college graduate women rose by 2.5 years in the $1970 \mathrm{~s}$, allowing them to be more serious students. The reversal of the college gender gap, rather than just its elimination, was due in part to the persistence of behavioral and developmental differences between males and females.
\end{abstract}

\author{
Claudia Goldin \\ Department of Economics \\ Harvard University \\ Cambridge, MA 02138 \\ and NBER \\ cgoldin@harvard.edu \\ Lawrence F. Katz \\ Department of Economics \\ Harvard University \\ Cambridge, MA 02138 \\ and NBER \\ $\underline{\text { lkatz@harvard.edu }}$ \\ Ilyana Kuziemko \\ Department of Economics \\ Harvard University \\ Cambridge, MA 02138 \\ kuziemko@nber.org
}




\section{Old and New Gender Gaps in Higher Education}

In 1960 there were 1.60 males for every female graduating from a U.S. four-year college and 1.55 males for every female undergraduate. Today the tables have turned. Women outnumber men in college. In 2003 there were 1.35 females for every male who graduated from a four-year college and 1.30 females for every male undergraduate. ${ }^{1}$

Despite the attention recently given to the new gender gap, women's relative numbers in college have increased with considerable continuity ever since the $1950 \mathrm{s.}^{2}$ This pattern is also not unique to the United States. The female share of college students has expanded in all OECD economies in recent decades. Women now outnumber men in college in most rich countries.

Another lesser-known fact is that the number of male to female undergraduates in the United States was about at parity from 1900 to 1930. Male enrollments began to increase relative to female enrollments in the 1930s and they soared directly following the end of World War II. A highpoint of gender imbalance in college attendance was reached in 1947 when undergraduate men outnumbered women 2.3 to 1 . From then on female college enrollments began to catch up, especially in the 1970s. Gender equality was again reached around 1980 and subsequently women overtook men in college enrollments and graduation rates.

The narrowing of the gender gap in enrollments to 1980 was a return or a "homecoming," although the levels of college going were almost six times higher in 1980 than in the 1920s for both men and women. This article explores the homecoming of American college women and the reversal in the gender gap in college attendance and graduation.

\footnotetext{
${ }^{1}$ The graduation data are for 1960-61 as it is the first that separates first professional degrees from bachelor's degrees (U.S. Department of Education 2005, table 247). The notes to Figure 4 give the source for undergraduate enrollment in 1960. The year 1960 is plausibly after the two GI Bills (for World War II and the Korean War) had run their course in college enrollments. Enrollments in Fall 2002 and graduates in 2002-03 are from U.S. Department of Education (2005, tables 176, 247).

${ }^{2}$ See, for example, the lead article, "The New Gender Gap," in BusinessWeek May 26, 2003.
} 
Four different periods in the college gender gap can be demarcated. From 1900 to 1930 female and male undergraduates were about equal in number. A great divergence then ensued for two decades, first during the Depression and later as GIs returned from World War II. Starting around 1950 female enrollments began to increase relative to male enrollments. But rather than stopping at equality in 1980, women's greater rate of increase continued. Women today have taken a distinct lead. We explore in detail the last two of these four periods-the catch-up and overtaking phases—using three longitudinal samples of high school graduating seniors in 1957, 1972, and 1992.

Young women who attended college from the late 1950s to the early 1970s did so mainly to pursue various female-intensive occupations, such as teaching and social work, to major in fields such as education, English, and literature, and to find suitable mates. Their reasons for attending college were fairly similar to those of generations of women who preceded them.

But beginning in the late 1960s and early 1970s young women's expectations of their future labor force participation radically changed. No longer did they anticipate that they would follow in their mothers' footsteps. Their labor force attachment would be far greater; they would have careers. In consequence, high school girls took more science and math courses; their twelfth grade math and reading test scores increased relative to those of boys. Most of these changes occurred during the 1970s and 1980s. We show that about 30 percent to 60 percent of the increase in the female to male ratio of college graduates from the 1970s to the 1990s can be explained by changes in these proximate determinants.

After the mid-1970s these young women, when in college, took more courses that led to careers rather than jobs and their elected majors were more investment than consumption oriented (Goldin 2005). College women could afford to be more serious scholars. The age at 
first marriage increased by about 2.5 years among college graduate women in the $1970 \mathrm{~s}$. Whereas the median college graduate woman from the 1950s to the early 1970s was married a little more than a year after graduation, by 1981 she married at 25 years old. Among the factors that led to an increase in the age at first marriage and to greater investment in professional careers was the availability of the contraceptive "pill” (Goldin and Katz 2002).

From the 1957 high school graduating class to that of 1992_our beginning and ending points - a clear leveling and then reversal can be discerned with regard to gender differences in college going and graduation. Females in the 1957 high school graduating class went to college and graduated at far lower rates than would have been expected based on their high school grades, aptitude test scores, and family background. Many of the best and the brightest did not continue to college. Fifteen years later the college gap had narrowed considerably. But young women still attended and completed college at lower rates than did comparable young men. The situation reversed in the next two decades and the 1992 female high school graduates continued to college and graduated with baccalaureate degrees to a greater extent than did males.

We can explain much of the convergence between male and female college going. But what accounts for the overtaking? The evidence is ambiguous on whether the lifetime economic rate of return to college is lower for males than females. An alternative possibility is the slower maturity of boys relative to girls and the greater incidence of developmental problems among boys. Because college preparation and applications must be done by teenagers, small differences in development can lead to large disparities in college outcomes. Although the consequences of such differences for college going are likely to be more extreme for those from disadvantaged backgrounds, they are found in almost all parts of the family-background distribution.

The playing field of life differed greatly by sex in 1957. As the playing field was leveled, 
developmental differences between boys and girls became more salient in explaining differences in educational attainment. These differences were, most likely, always there, but were less apparent when large differences existed between male and female aspirations and before college education became more accessible to the children of low-income parents.

\section{Historical and Comparative Evidence}

A. Historical evidence on the four phases

The emergence of a "new gender gap" in higher education can be observed using various college outcomes, such as college or post-secondary school enrollment and the receipt of a bachelor's (four-year college) degree. The evidence can be either contemporaneous, from administrative data, or cohort based, from census and other surveys. The decline in the male to female ratio of undergraduates during the past 35 years is real and is not due primarily to changes in the ethnic mix of the college-aged population or to the types of post-secondary institutions they attend. ${ }^{3}$ We use various definitions for the administrative and the census data and will show that the results are remarkably similar.

College graduation rates by birth cohort are given in Figure 1, which shows a century of four-year college graduation rates beginning with the cohort born in 1876 and measured when it was approximately 35 years old. A fairly steady increase in the graduation rate of men is apparent from the start of the series to the peak reached during the Vietnam War by the late

\footnotetext{
${ }^{3}$ The substantial decrease in the ratio of male to female undergraduates is apparent for all ethnic and racial subgroups including Hispanics, white non-Hispanics, and black non-Hispanics, for all types of institutions including research universities, liberal arts colleges, public institutions, and private institutions, and for both full-time and part-time enrollment. See the Integrated Post-Secondary Education System (IPEDS) data at http://caspar.nsf.gov. The female advantage in college enrollment and graduation is now substantially larger for Hispanics and black non-Hispanics than for white nonHispanics.
} 
1940s birth cohorts. ${ }^{4}$ Although the series for women was high early on, it began to trail the male series with birth cohorts of the 1910s (who reached college age during the Depression). The female series continued to fall further behind with the cohorts affected by the World War II and Korean War GI bills. ${ }^{5}$ But starting with those born in the mid-1930s, and especially with those born in the late 1940s, females increased their college graduation rates relative to males.

By the cohort born around 1950 the relative graduation rate of men to women was 1.25 , about equal to that achieved earlier in the century for cohorts born from 1880 to 1910 (Figure 2). The "homecoming" — the return to the previous level—had taken three decades. Parity was reached in just one more decade, by the cohorts born in 1960, and the female advantage widened considerably in the next decade. ${ }^{6}$

The data expressed in difference form (Figure 3) alter the observations from the ratios in one major respect. The change for both college graduation rates and attendance at college, rather than beginning with the 1930s cohorts, occurs for the cohorts born in the late 1940s and the catch-up is extremely rapid.

The data from the household surveys (census) are fully consistent with administrative data from higher education institutions. We have graphed the administrative enrollment data against the cohort data from Figure 2 on any college (with 20 years added to the birth year) to produce Figure 4. The two series for the ratio of college males to females closely track each other except during and immediately following World War II. ${ }^{7}$

\footnotetext{
${ }^{4}$ Card and Lemieux (2001) assess the impact of the Vietnam War draft on the college enrollment and educational attainment of men relative to women in the affected cohorts.

${ }^{5}$ Bound and Turner (2002) and Stanley (2003) provide detailed analyses of the impact of the GI bills on male educational attainment.

${ }^{6}$ The ratio of the college attendance data (Figure 2) is similar to that for the graduation rates.

${ }^{7}$ The cohort series measures whether individuals attended any college whereas the contemporaneous series is implicitly weighted by years in college. Thus the latter is a somewhat more exaggerated version of the former. An alternative household survey measure of college enrollment for 18 to 21 year olds from
} 
B. Accounting for change in the first half of the twentieth century

We have outlined four phases in the evolution of college going rates for men and women. Because our focus here is on the last two of the phases, we briefly summarize the reasons for change for the first two.

Relative equality in the first of the phases existed for enrollments, somewhat less for graduation rates. The difference between the two measures occurred largely because women attended teacher-training colleges many of which had two-year programs. In 1925, for example, 30 percent of the female enrollments were at teacher-training schools whereas just 8 percent of the male enrollments were. ${ }^{8}$

Parity in college enrollments, during the first phase, was not produced by an elite class whose children went to college equally by sex, as was often the case in England. Just 5 percent of the women enrolled in privately controlled colleges in 1925 attended the elite "seven-sister" schools and only 22 percent were in any women's college. Half of all American college students in 1925 were in publicly-controlled institutions of higher education (55 percent of women were).

More difficult to understand is why women, whose life time labor force participation rates when married were low, went to college at almost equal rates as did men, whose participation rates were much higher. One answer is that a substantial fraction of the women who graduated in these early classes never married. Those who did were far more likely to marry a college-educated man. The return to college was garnered, separately, through the labor and the marriage markets (Goldin 1997).

The college gender gap began to widen in favor of men during the 1930s when

the October Current Population Surveys shows a similar pattern of decline in the male/female enrollment from 1.41 in 1970 to 0.81 in 2003 with gender parity reached in 1981 .

${ }^{8}$ Data on enrollments by sex and type of institution of higher education from the 1920s and 1930s come from the U.S. Office of Education, Biennial Reports, for various years. 
unemployment left many with little else to do and a college degree could enhance employability. Marriage bars—regulations that barred married women from employment—were extended in many school districts making a teaching degree less valuable for women (Goldin 1991). In fact, the number of women in teacher's colleges declined substantially from 1929 to 1935 while the number of men increased. Had the teaching-college enrollments remained at their 1929 levels, male to female overall enrollment ratio in 1935 would have been 1.15 rather than 1.26 , far more like the 1929 overall level of 1.09.

The vast change with returning World War II GIs appears to be a rather different story. The costs of attending college decreased considerably and affected men far more than women, especially with substantial educational subsidies through the GI bills. Whereas men continued to enter teaching at greater rates than women —in part due to the greater demand for high school teachers - the impact on total college enrollments was small. College had expanded across the ranks of Americans and had become an entry requirement for a significant number of jobs.

C. College gender gaps across nations

Not only has the gender gap in college attendance and graduation reversed in the United States in the past decades, but the data for most other nations also show substantial relative gains for females. Of the 17 OECD countries with consistent tertiary schooling enrollment data for 1985 and 2002, as displayed in Figure 5, only 4 had a ratio of male to female undergraduates that was below one in 1985 but 15 did by 2002. Just two countries out of the 17 had a ratio in 2002 that was greater than one but both had a declining gender gap from 1985 to 2002. Almost all countries in the OECD now have more women than men in college and have had a growing gender gap among undergraduates that in recent years favors women. Any explanation of the U.S. trends must be consistent with these worldwide changes. 
III. Evidence on College Outcomes from Longitudinal Samples of High School Seniors

A. Proximate determinants of college outcomes

Youth must plan for college in high school. Thus we start with a set of proximate changes in their college preparation using three longitudinal surveys of high school pupils and we limit the samples to graduating seniors. Two of the surveys are nationally-representative: the 1972 National Longitudinal Survey (NLS), a sample of high school seniors in the spring of 1972, and the 1988 National Educational Longitudinal Survey (NELS), a sample of eighth graders in the spring of 1988 who were seniors in $1992 .{ }^{9}$ Because the ascent in young women's college going began earlier we also use the less familiar Wisconsin Longitudinal Survey (WLS), which commenced in 1957 with one-third of all graduating seniors in the state of Wisconsin. ${ }^{10}$

The proximate determinants of college going are high school grades (rank), aptitude (or achievement) test scores, and courses taken. We find considerable narrowing between males and females in test scores and college-oriented courses particularly in the 1970s and 1980s.

In all three surveys, girls achieved considerably higher grades in high school than did boys (Part A of Tables 1, 2, and 3). In the WLS (graduating 1957) the high school rank of the median girl was 21 percentile points above the median boy. In the NLS (graduating 1972) the median girl was 17 percentile points above the median boy and the difference was almost 16 percentile points in the NELS (graduating 1992). Boys, however, took more science and math courses in 1957 and 1972, a factor to which we will soon return.

\footnotetext{
${ }^{9}$ Information and documentation for the 1972 NLS is available at http://nces.ed.gov/surveys/nls72/, and that for the 1988 NELS is available at http://nces.ed.gov/surveys/nels88/. We use the restricted-access version of the NELS to analyze information on high school courses and high school rank.

${ }^{10}$ The documentation and data for the WLS is available at http://dpls.dacc.wisc.edu/wls/index.html.
} 
Whereas girls always achieved a higher class-rank than boys, aptitude and achievement tests show a different pattern. For 1957 graduates, junior-year IQ scores-the only test available in the WLS—display almost identical distributions by sex (Part A, Table 1). Separate (twelfth grade) math and reading achievement test scores available first in 1972 show that boys did far better in math whereas girls did better in reading. ${ }^{11}$ But by 1992 girls had widened their lead in reading and narrowed the gap with boys in math. From 1972 to 1992 girls gained about 0.17 of a standard deviation in both math and reading, and thus by 1992 girls had an advantage in the composite achievement score. $^{12}$

The courses taken by high school graduates are another part of their college preparedness and, other than foreign languages, math and science courses are most predictive of college attendance and completion. In 1957 boys took far more math and science courses then did girls (Table 4). The difference in 1957 is particularly striking for advanced math courses, chemistry, and physics. But by 1992 there was virtual parity in almost all science and math courses, and girls remained considerably ahead of boys in foreign languages. ${ }^{13}$ The greatest advances for girls relative to boys in the math and science courses occurred between 1972 and 1982.

B. College outcomes

For consistency across the three samples, the B.A. degree (four-year college degree)

\footnotetext{
${ }^{11}$ There is little reason to believe that scores would have been much different by sex in 1957 and the composite scores created in 1972 for comparison with the WLS have distributions similar to those for IQ. ${ }^{12}$ The finding of large relative gains in both math and reading scores for females is robust and holds for non-Hispanic whites and all high school seniors. Cho (2005) also reports large relative gains for females from 1972 to 1992 using the NLS and NELS samples. A well-known standardized test given to 17-year olds (or eleventh graders) the National Assessment of Educational Progress (NAEP) shows a 0.12 standard deviation gain in math scores for females relative to males from 1973 to 1992 and a small gain in female relative reading scores from the mid-1970s to 1996 (U.S. Department of Education 2004). We are not certain why the female relative gains are somewhat smaller in the NAEP.

${ }^{13}$ The trend toward full parity has continued. For example, in 2000 the male to female ratio for overall science courses was 0.97 and was 1.21 for physics (U.S. Department of Education 2004, table 137).
} 
outcome measure is used. ${ }^{14}$ The 1957 high school graduating class (born around 1939) had, by 1964, a female college graduation rate that was 66 percent the male rate. The ratio varied little across the IQ distribution. Even at the top, the ratio of female to male college graduates was almost equal to the average and was 64 percent in the second to the top IQ decile, for example (see Table 1, Part B). Because girls did much better than did boys in high school it is not surprising that boys went to college at enormously higher rates at every high school rank decile given average college graduation rates. The girl in the second to the highest high school rank decile had a college graduation rate similar to that of the median boy. Regardless of aptitude, high school rank, and family background, about which we will have more to say, girls in the 1957 high school class had college graduation rates that were considerably lower than those of comparable boys.

In 1979, seven years after graduation for the NLS seniors, the ratio of females to males obtaining a B.A. was 0.87 . Not only did more females relative to males graduate from college but the relationship between the fraction completing a B.A. and high school rank (or achievement score) steepened for both males and females but especially for the latter. In 2000, eight years after the NELS seniors graduated, the ratio of female to male college graduates was 1.21. Whereas the advantage for males had been 3.9 percentage points for the 1972 graduating class, the advantage for females was 7.3 percentage points for the 1992 class. ${ }^{15}$ The enormous catch-up in college outcomes and leapfrogging for females are found in all portions of the ability distribution. Female high school graduates in 1957 even from the top third or higher of their

\footnotetext{
${ }^{14}$ The levels for the fraction obtaining a B.A. degree about seven years after high school graduation from these three longitudinal samples are in line with the other national data such as the Census data shown in Figure 1 and March Current Population Survey data. The trends in the college gender gap across our three surveys are quite similar when using B.A. completion or alternative measures of college attendance. ${ }^{15}$ These gender gaps in B.A. completion refer to the NLS and NELS samples with complete information on test scores and high school rank. The means by sex for these samples are given in Table 7 .
} 
class were not immune to the normative constraints and real barriers of their day. From the 1957 class to that in 1972, as college going and graduation rates increased among young women relative to men, the greatest changes were initially among the brightest and highest-achieving women and increased sorting on the basis of ability. From 1972 to 1992 relative increases in female graduation rates were found throughout the achievement distribution, although the movement was somewhat larger at the center.

C. Explaining change in college outcomes using the proximate determinants

The proximate determinants discussed previously are not independent of each other and a regression framework can be used to separate the role of each to see how much the changes in these characteristics explain the narrowing of the college gender gap. ${ }^{16}$ A simple OLS, linear probability model for B.A. completion is employed where the independent variables include high school rank (in percentiles), aptitude (normalized as z-scores), high school courses, and family background, such as parental income, mother's education, race, and ethnicity. ${ }^{17}$ Our measure of aptitude is the normalized reading and math achievement test scores, except in 1957 when it is the normalized IQ score. For the comparison between 1957 and 1972 we use a composite reading and math aptitude score for 1972 and restrict 1972 to (non-Hispanic) whites. ${ }^{18}$ Pooled regressions for males and females in Table 5 enable comparisons between 1957

\footnotetext{
${ }^{16}$ Cho (2005) provides a complementary analysis of gender differences in college attendance within two years of high school graduation for high school seniors from 1972, 1982, and 1992. Long (2005) examines the increase in the female to male college enrollment ratio using state-panel data from 1972 to 1998. Her results indicate that states with a greater growth in finance-sector employment and slower growth in public college tuition for flagship institutions experienced greater increases in the ratio. Charles and Luoh (2003) study the role of changes in the college wage premium and anticipated dispersion of future wages on the gender gap in educational attainment.

${ }^{17}$ The regression samples are slightly smaller than the full samples for the descriptive tabulations in Tables 1,2, and 3 because we delete observations with missing B.A. completion, test score, or high school rank information from the regression samples. We include dummy variables for missing data for the other independent variables in the regressions.

${ }^{18}$ Race was not given in the WLS but the presumption is that almost all the students were white. The 1960 U.S. census indicates that 97 percent of Wisconsin residents in the 1939 birth cohort were white.
} 
and 1972 and in Table 6 between 1972 and 1992. Three groups of independent variables are included for each of the years beginning with aptitude, then adding high school rank percentile, and math and science courses. All regressions, except the estimates of raw gender differences in col. (1), include a set of family background variables.

The gender gap in B.A. completion in favor of males for the 1957 high school graduating class is 6.7 percentage points (Table 5) adjusted only for family background factors. ${ }^{19}$ Because girls outperformed boys in high school but graduated from college at considerably lower rates, the coefficient on the female dummy almost doubles in absolute value when high school rank percentile and IQ decile are added. The addition of semesters of math and science courses shrinks the gender gap back to 7.5 percentage points. Thus the covariates taken together do nothing to explain the gross gender difference in 1957.

In the comparable regressions for 1972 the gender difference in B.A. completion at the means, adjusted only for family background factors, decreases to 2.4 percentage points. The addition of test scores, high school rank, and courses slightly increases the female deficit to 3.2 percentage points. Once again, the gap is not narrowed by these proximate determinants.

The comparison given in Table 6 shows that the female disadvantage of almost 2 percentage points in 1972 reversed to an advantage of more than 9 percentage points in 1992, for a total gain of 11 percentage points. The addition of the full set of variables (col. 5) in 1992 reduces the female coefficient by 40 percent of its gross value ( 0.055 versus 0.091$)$. Whereas almost none of the difference could be explained for the 1957 and 1972 graduating classes, about 40 percent can be explained for 1992.

Similar estimates are given in Table 7 separately by sex for 1972 and 1992 on the full set

\footnotetext{
${ }^{19}$ We use the family background adjusted values because the males dropped out of high school at higher rates than did females from more disadvantaged families.
} 
of variables. Even though the typical high school senior female in 1972 had a high school rank considerably above that of her male counterpart, the importance of her rank paled in comparison. Each percentile rank point for the girl was worth just 0.6 that for the boy $(0.295 / 0.472)$. But in 1992 the situation had reversed and each percentile rank point for a girl was worth almost 1.6 times that for a boy. Because girls gained on boys in taking science and math courses, their improved college preparedness is a key factor accounting for the increase in their B.A. completion and the increase is magnified by the greater importance of math and science courses from 1972 to $1992 .{ }^{20}$ Finally, the large increase in math and reading scores for girls relative to boys from 1972 to 1992 positively impacted their B.A completion rate.

What role did the proximate determinants (high school test scores, courses, and grades) play in the reversal of the gender gap in college graduation from the mid-1970s to the mid1990s? One approach to answering the question involves comparing the change in the female coefficient from 1972 to 1992 for the regression including all the proximate determinants (col. 5 of Table 6) with changes in the raw gender differential adjusted for family background variables (col. 2 of Table 6). The change in the female coefficient, from 1972 to 1992, given by the col. (5) estimates is 8.0 percentage points $(0.055+0.025)$ as compared with the 11.0 percentage point raw change given in col. (2). Thus, 3.0 percentage points or 27 percent of the raw change is explained. This approach values gender differences in the proximate determinants in each year (1972 and 1992) by the coefficients in that year.

An alternative approach uses the coefficients from col. (5) of Table 6 for each of the two years 1972 and 1992, separately, multiplied by the change in the gender differences in the means of the proximate determinants (from Table 7). The use of 1972 (1992) coefficients answers the

\footnotetext{
${ }^{20}$ The comparison between 1972 and 1992 must account for the shift from semesters to Carnegie units (about 0.6 semesters equaled one Carnegie unit).
} 
counterfactual of how different the gender gap in college completion would have been in 1972

(1992) if the gender gap in proximate determinants had been that prevailing in 1992 (1972).

Using the 1972 coefficients, the three proximate determinants together explain 37 percent of the total change, whereas using the 1992 coefficients they explain almost 63 percent. The difference comes almost entirely from the increased importance of math and science courses in 1992. The relative increase in girls' test scores explains about 1.5 of the 11 percentage point increase, however the decrease in their high school rank (girls increased their load of "harder" courses) lowers the explained total. Girls' relative increase in math and science courses adds 3.3 percentage points using the 1972 weights and a whopping 6.2 points using the 1992 weights. $^{21}$

D. Family socio-economic status

The conventional presumption has been that more-educated parents and families with greater economic resources would be relatively gender neutral in their willingness to pay for their children's education, whereas those lower down in the socio-economic status (SES) distribution would tend to favor sons over daughters when they could afford to educate only some. Thus, secular increases in parental education and family income would tend to improve female relative college outcomes. ${ }^{22}$

Table 8 and Figure 6 show the patterns of college completion rates by sex and parental SES quartile for the high school graduating classes of 1957 (WLS), 1972 (NLS), and 1992 (NELS) using the standard SES composites based on parental education, income, and

\footnotetext{
${ }^{21}$ The full contribution of the proximate determinants using the 1972 weights is 4.06 percentage points or 36.9 percent of the total; using the 1992 weights the contribution is 6.89 percentage points or 62.6 percent of the total. Because the 1992 courses are measured in Carnegie units and those in 1972 are measured in semesters, we use the difference in the ratios of female to male courses in the two years scaled by the absolute level of courses in each of the years to obtain comparable units. This method is almost equivalent to using the approximation that each Carnegie unit is worth 0.6 semesters. The means for the course variable in 1972 used in this calculation exclude observations with missing values for courses.

${ }^{22}$ See Buchmann and DiPrete (2005) who use the General Social Survey aggregated across many cohorts to examine how changes in parental education and resources have affected the college gender gap.
} 
occupational status. The conventional presumption holds in 1957. A far lower ratio of females to males graduated from college in the bottom half of the SES distribution than in the top half. From 1957 to 1972 females gained on males throughout the SES distribution, and gender parity in college graduation was reached in the top SES quartile by 1972. From 1972 to 1992 females moved ahead of males in college completion at all SES levels. The proportional gains, however, were greatest in the lower SES quartiles. In fact, the conventional SES pattern of college gender differences reversed itself over this period.

By the 1990s the ratio of females to males graduating from college became considerably higher in the lower half of the SES distribution than in the upper half. These trends in the college gender gap by SES in recent decades are similar for white, non-Hispanics and for the entire U.S. population (as seen by comparing panels A and B of Table 8) and also hold when parental education and income are used separately as the family background indicators.

The bottom line is that a substantial female lead in college graduation rates is now found at all SES levels and even for the children of high-income parents. Nevertheless, the new gender gap in college education favoring females is greatest in the lower half of the SES distribution.

\section{Understanding Trends in the College Gender Gap}

\section{A. Human capital investment framework}

Changes in the proximate determinants can explain a substantial portion of the closing of the college gender gap. But two elements remain in understanding trends in the college gender gap. One is that the proximate determinants are, themselves, determined by other factors, for example by the expectations of young women about their future employment, marriage, and family. Another is that the college gender gap has not just narrowed. It has reversed. To 
provide both of these missing elements requires reference to a simple, and well-known, framework concerning the decision to attend college.

Individuals weigh the costs of attending and graduating from college against the benefits from college. The benefits include the direct labor market returns to college, which depends on expected employment probabilities for those who attend college versus those who stop at high school graduation and the time path of earnings for both (thereby implicitly including the opportunity cost of college). Other possible benefits are the consumption value of higher education, its influence on one's health and parenting skills, and the role college plays in the marriage market, perhaps the most important additional factor for the issues we consider here. Because these benefits are deferred, their value also depends on the subjective discount rate.

The costs to the individual include the direct outlay for college, potential financing constraints, and the effort costs of college attendance and college preparation during high school, about which we will have more to say. Other factors that may have differentially impacted males and females are the constraints imposed by the admission policies of institutions of higher education, such as capacity constraints and the barring of one sex from particular institutions. ${ }^{23}$

The most important factors that we will consider are those that differed by sex or differed in their consequences. These include changing expectations of future labor force participation, the age at first marriage, and behavioral problems. The first two factors help explain the convergence between male and female college outcomes. The expectations of future labor force participation greatly increased for female youth beginning in the 1960s and extending into the late 1970s. This change combined with a high college wage premium for women increased the

\footnotetext{
${ }^{23}$ Currie and Moretti (2003) provide suggestive evidence of the easing of such supply constraints for U.S. women born from 1925 to 1975 with shifts of male-only to coed colleges. In particular, they find that the transformation from a male-only to a coed college in one's county of residence as a youth is associated with an increase in female educational attainment.
} 
expected labor market return to college investments. The age at first marriage rose for both men and women, especially during the 1970s. But the increase impacted women's decisions more than it did men's. Behavioral problems have always been worse for boys than for girls and may help explain why females have passed males in college going rather than stopping at equality.

B. Changing expectations, social norms, and the age at first marriage

The expectations of young women about their future labor market participation can be gleaned from the National Longitudinal Survey of Young Women (NLS68) which surveyed 14 to 24 year old females beginning in 1968 and the National Longitudinal Survey of Youth 1979 (NLSY79) which surveyed 14 to 21 year olds beginning in $1979 .^{24}$ Respondents were asked whether they would be "married, at home, with family" or "at work" when they were 35 years old. We have arrayed the data from these surveys in Figure 7 holding the age of the respondent constant for three age groupings - 16 to 17,18 to 19 , and 20 to 21 years old. In all cases the fraction who thought they would be "at work" began low-around 30 to 35 percent in 1968 and 40 to 45 percent in 1969 - but rose almost continuously until the late 1970 s when it reached about 80 percent. $^{25}$ Although the rate of increase was great, it was not until the late 1970s that the expectations of young women caught up with their eventual labor force participation when they were 35 years old.

A somewhat related question—concerning attitudes toward working married women— was asked in the Astin Freshmen Survey, a national sample of college freshmen the vast majority of whom were 18 years old, (Astin, et al. 2002). In 196741 percent of freshmen women thought it would be improper for a married woman to work but just seven years later in 1973 only about 17 percent did. As in the case of work expectations, the change in attitudes towards women's

\footnotetext{
${ }^{24}$ Information on the NLS68 and NLSY79 is available at http://www.bls.gov/nls/home.htm.

${ }^{25}$ The question asked in 1968 differs somewhat from that asked in subsequent years.
} 
employment after marriage changed substantially between the late 1960s and the early-1970s. ${ }^{26}$

Rising expectations of future employment encouraged young women to attend and graduate from college. We demonstrate in Table 9 that large differences existed between the college attendance and completion rates of young women who stated mainly prior to leaving high school that they were planning to be in the labor force at age 35 years. Because there is noise in the responses, we focus on those who stated in both 1969 and 1970 that they expected to be in the labor force. For those who were 15 to 19 years old in 1969, the group who answered in the affirmative had an eventual college graduation rate of 0.328 . Those who answered that they would be "at home" had a college graduation rate of 0.185 , thus the difference is 0.143 . For those 15 to 18 years old the difference is 0.121 . Since the fraction expecting to be in the labor force at age 35 increased by about 40 percentage points from 1968 to 1979 , the change in expectations would account for a 4.8 to a 5.7 percentage point increase in college graduation or about the entire increase from the 1949 birth cohort (0.22) to that of $1965(0.27)$.

Not only did expectations of future labor force participation and social norms change from the late 1960s to the mid-1970s, there was, as well, startling demographic change. Young women in the 1950s, even those who eventually graduated from college, could expect to marry young and have several children. Because the age at first marriage was so low for these cohorts (the median was under 23 years), a young woman who had not secured a husband while she was in college would have been rather tense, possibly panicky, at graduation (see Goldin 1997 on the

\footnotetext{
${ }^{26}$ The precise comment was: "The activities of married women are best confined to the home and family." Figure 6 gives ( 1 - the fraction agreeing) for 1967 to 1984 . A greater fraction of male than female freshmen agreed with the question in all years (54 percent in 1967). However the change in the attitudes of males corresponds to that of females (percentage agreeing declined to 27 percent in 1973). These changes are not a figment of the data or the question asked. The transformation in the attitudes of college men about the paid work of married women may also have encouraged young women to further invest in college and labor market skills. See Fernández, Fogli, and Olivetti (2004) for an insightful analysis of how changes in male attitudes can affect women's labor force participation, fertility, and educational investments.
} 
gains from college in the marriage market). In consequence, college was often taken less seriously. But after staying constant for decades, the age at marriage began a rapid ascent.

The median age at first marriage among female college graduates increased by 2.6 years, from 22.4 to 25 years old, for cohorts born from 1947 to 1957 (and graduating college from about 1969 to 1979). The marriage age continued to increase so that by the cohort born in 1968, and finishing college in about 1990, the median age at first marriage was 26.4 years. ${ }^{27}$ Many factors were at work, most notably technological changes affecting contraception such as the birth control pill (Goldin and Katz 2002). ${ }^{28}$

C. Why did change occur?

The reasons for the surge in women's relative college going after the 1960s can be found in two transformations in the post-World War II era that greatly increased the pecuniary return to women's higher education. The first transformation was an increase in life cycle labor force participation but with little change in occupations. The second transformation was a further increase in labor force participation and a large shift out of the most traditionally female occupations for women. Each of these changes increased the returns to a college degree.

The early post-war cohorts of female college graduates (those born from 1926 to 1930, leaving college in the late 1940s and early 1950s) had high fertility (they were, after all, the mothers of the Baby Boom), low labor force participation rates in their twenties and thirties, and worked most often in traditionally female-dominated occupations. As 30 to 34 year olds (in 1960), 39 percent were employed (26 percent full-time), 73 percent had children at home, and 47

\footnotetext{
${ }^{27}$ These tabulations use the 1990 and 1995 Current Population Survey Fertility supplements. We estimate the median age of first marriage as the mean age of first marriage of those from the $48^{\text {th }}$ to $52^{\text {nd }}$ percentiles of the age of first marriage distribution for college graduate women in each birth cohort. ${ }^{28}$ Goldin and Katz (2002) find that young women's access to the pill has a positive impact on postcollege education, high-powered professional careers, and the age at first marriage. Hock (2004) examines the impact of the pill on female college going and graduation. Bailey (2006) estimates substantial effects of pill access in increasing female labor force participation and the age at first birth.
} 
percent of those employed were teachers (see Table 10). Female college graduates born a decade later, from 1936 to 1940, had similar fertility rates (they too were Baby Boom mothers) and had similar occupations. The big difference between that cohort and the previous one was its substantially higher labor force participation: 49 percent were employed at ages 30 to 34 . Contrast this cohort with that born another decade later, from 1946 to 1950 . When this cohort of female college graduates were 30 to 34 years old, 70 percent were employed (55 percent fulltime), 60 percent had children at home, and only 36 percent of those employed were teachers.

Rapidly changing expectations among young women concerning their future life-cycle labor force participation started in the late 1960s. An important reason for the change is that female college graduates of the previous generation increased their participation rates in the 1960s and the 1970s (Table 10). Thus teenage girls could look around and see the world was swiftly changing and extrapolate on the basis of generational change. Their expectations, however, appear to have exceeded any reasonable set of extrapolations based on previous changes, but were fairly good predictors of their own future participation.

Another candidate - the widespread legality and acceptance of the "pill" as a birth control device for single women - allowed young women to better plan their futures and also helped facilitate a large increase in the age at first marriage particularly among college educated women. Other factors include the resurgence of feminism, which empowered young women, and greater guarantees by the government that discrimination against women would not be tolerated.

Thus, young women anticipated a more even playing field with respect to young men in terms of access to high-paying careers for college graduates and to professional and graduate programs. Expectations of a large labor market payoff to college were reinforced in the 1960s and especially since 1980 by a rising college wage premium and by secular labor demand shifts 
favoring occupations and industries disproportionately employing college-educated workers, particularly female college graduates (Katz and Murphy 1992).

Rising expectations led to the better preparation of young women for college and the world of work. The largest narrowing in the gender gap in high school math and science courses occurred between 1972 and 1982, even though there was convergence during the entire period from 1957 to 2000 . Better preparation eventually paid off as girls advanced greatly in math and reading test scores, relative to boys, from around 1980 to $1992 .^{29}$ Not only did girls advance to college at greater rates and eventually at rates exceeding those of boys, but they also began to take courses and major in fields that were more career-oriented, especially since the mid-1970s. Whereas women earned only 9.1 percent of all bachelor's degrees in business in 1970-71, they earned 45.1 percent of such degrees in 1984-85 and 50 percent by 2001-2. Disproportionately large increases in the female share of B.A.'s have also occurred in the life sciences, physical sciences, and engineering since the early 1970s (Wirt et al. 2004).

D. Sources of the college gender gap reversal

Why have females surpassed males in college going and college completion and not simply caught up to them? Once barriers to female careers were lowered and their access to higher education was expanded, two key factors may have played a role in the female college advantage: relatively greater economic benefits of college for females and relatively higher effort costs of college going and preparation for males.

According to most estimates, the college (log or percentage) wage premium is actually higher for women than men, and it has been higher for some time (Dougherty 2005). But women discounted the higher college wage premium because of their much lower lifetime labor

\footnotetext{
${ }^{29}$ We say between 1980 and 1992 because our data shows a marked increase in girl's scores from 1972 to 1992 but Cho (2005) who uses the "High School and Beyond" sample for 1980 finds almost no change in the gender gap in scores from 1972 to 1980.
} 
force participation. More recently, however, their participation has begun to resemble men's. Women, in turn, have responded to the full monetary returns, which have increased absolutely and relatively. ${ }^{30}$ The jury is still out concerning whether the full lifetime economic returns to college are greater for women than for men. But the future economic benefits of post-secondary schooling now appear at least as important for them. Added to these factors is the rise in divorce rates since the 1960s and women's greater economic responsibility for children, both of which would contribute to an insurance-based motive for college investment.

Another reason for the reversal of the college gender gap is that girls have lower nonpecuniary (or effort) costs of college preparation and attendance than boys. Evidence consistent with this view is that girls have exceeded boys in secondary school performance and attainment at various times during the last century even when the labor market barriers faced by women meant substantially lower expected labor market returns to schooling for girls than boys. ${ }^{31}$

One source of the persistent female advantage in K-12 school performance and the new female lead in college attainment is the higher incidence of behavioral problems (or lower level of non-cognitive skills) among boys. Jacob (2002) finds, using the NELS, a much higher incidence of school disciplinary and behavior problems for boys than girls and a far lower number of hours spent doing homework for boys than girls. Controlling for these non-cognitive behavioral factors can explain virtually the entire female advantage in college attendance for the high school graduating class of 1992, after adjusting for family background, test scores, and high school achievement. Similarly, we find that teenage boys, both in the early 1980s and late 1990s, had a higher (self-reported) incidence of arrests and school suspension than teenage girls,

\footnotetext{
${ }^{30}$ Some evidence suggests the mean family income gap between those with college and high school degrees had become modestly greater for young women ( 25 to 34 years old) than for young men by 2000 (DiPrete and Buchmann 2006).

${ }^{31}$ The current gender gap in college curiously mimics that found in high school, particularly for graduates, across the nation in the early part of the twentieth century (Goldin 1998).
} 
and that measures of behavioral problems significantly attenuate the female college advantage. ${ }^{32}$ Reinforcing these findings is evidence that boys have two to three times the rate of Attention Deficit Hyperactivity Disorder (ADHD) than girls and much higher rates of criminal activity (Cuffe, Moore, and McKeown 2003; Federal Bureau of Investigation 2004). Boys are also much more likely than girls to end up in special education programs. ${ }^{33}$ The source of boys' higher incidence of behavioral problems is an area of active research and could be due to their later maturation as well as their higher rates of impatience (Silverman 2003). Because gender differences in development and behavior are not unique to any particular country, they can explain why the reversal of the gender gap in college has occurred throughout much of the developed world once female access to college and to labor market opportunities were improved.

\section{The Reversal of the College Gender Gap: Summary}

Women are now the majority of undergraduates and those receiving a bachelor's degree. But this change did not occur overnight. Rather, it began with the 1930s birth cohorts, and the progression was halted only during the Vietnam War when large numbers of men attended college to avoid the draft. Although the relative increase occurred almost continuously, far larger changes took place in the late 1960s and 1970s. The upward trend in women's college attendance in the twentieth century returned the gender balance to its pre-1930 level by 1980 . In that sense, the change was a "homecoming."

Between 1957 and 1972 high school girls increased their college going rates to a considerable degree but had not yet advanced in their measured cognitive achievement relative to boys, particularly in math. By the end of the 1970s, however, girls had more realistic notions of

\footnotetext{
${ }^{32}$ These findings are from an analysis of the 1979 and 1997 NLSY samples.

${ }^{33}$ Personal communication from Janet Currie based on tabulations from the Children's sample of the 1979 NLSY.
} 
their future labor force participation and could prepare better for college. Between 1980 and 1992 girls' test scores advanced on those of boys and from 1972 to 1982 their high school courses became considerably more math and science oriented.

The most obvious reason for these changes is that the direct return to women from attending college increased with the rise in women's life-cycle labor force participation and their greater ability (and desire) to do post-graduate work in professional schools and elsewhere. The increase in the age at first marriage enabled college women to be more serious about their studies and less concerned about securing a husband while completing their undergraduate degree. With the diffusion of more effective birth-control methods, those who were investing in education could take women more seriously.

The relative increase in female to male college graduates from the 1960 s to the 1990 s is found across all quartiles of the income and socio-economic status distribution of families. Although the greatest increases since the 1980s occurred in the bottom half, the reversal of the college gender gap is apparent throughout the distribution.

A more level and wider playing field for girls enabled them to blossom. At the same time, the slower social development and more serious behavioral problems of boys remained and allowed girls to leapfrog over boys in the race to college. The end result is a current gender imbalance among college undergraduates in the United States and elsewhere. 


\section{References}

Astin, Alexander, W., Leticia Oseguera, Linda J. Sax, and William S. Korn. 2002. The American Freshman: Thirty-Five Year Trends, 1966-2001. Los Angeles, CA: Higher Education Research Institute, Graduate School of Education and Information Studies, UCLA.

Bailey, Martha J. 2006. "More Power to the Pill: The Impact of Contraceptive Freedom on Women's Life Cycle Labor Force Participation," Quarterly Journal of Economics 121 (February), 289-320.

Bound, John and Sarah Turner. 2002. "Going to War and Going to College: Did World War II and the GI Bill Increase the Educational Attainment for Returning Veterans?" Journal of Labor Economics 20 (October): 784-815.

Buchmann, Claudia and Thomas A. DiPrete. 2005. "The Growing Female Advantage in Higher Education: Do Gains in Parental Resources Explain the Trends?" Ohio State University unpublished paper.

Card, David and Thomas Lemieux. 2001. "Going to College to Avoid the Draft: The Unintended Legacy of the Vietnam War," American Economic Review 91 (May): 97-102.

Charles, Kerwin C. and Ming-Ching Luoh. 2003. "Gender Differences in Completed Schooling," Review of Economics and Statistics 83 (August): 559-77.

Cho, Donghun. 2005. “The Role of High School Performance in Explaining Women's Rising College Enrollment." University of California at Santa Barbara, unpublished paper (May).

Cuffe, Steven, Charity Moore, and Robert McKeown. 2003. "ADHD Symptoms in the National Health Interview Survey: Prevalence, Correlates, and Use of Services and Medication." Poster presented at the Fiftieth Anniversary Meeting of the American Academy of Child and Adolescent Psychiatry, Miami, October 20.

Currie, Janet and Enrico Moretti. 2003. "Mother's Education and the Intergenerational Transmission of Human Capital: Evidence from College Openings," Quarterly Journal of Economics 118 (November): 1495-1532.

De Long, J. Bradford, Claudia Goldin, and Lawrence F. Katz. 2003. "Sustaining U.S. Economic Growth." In H. Aaron, J. Lindsay, and P. Nivola, eds., Agenda for the Nation. Washington, D.C.: Brookings Institution Press, pp. 17-60.

DiPrete, Thomas A. and Claudia Buchmann. 2006. "Gender-Specific Trends in the Value of Education and the Emerging Gender Gap in College Completion," Demography 43 (February), forthcoming. 
Dougherty, Christopher. 2005. "Why are Returns to Schooling Higher for Women than for Men?” Journal of Human Resources 40 (Fall): 969-88.

Federal Bureau of Investigation. 2004. Crime in the United Sates, 2003. Washington, D.C.: U.S. G.P.O.

Fernández, Raquel, Alessandra Fogli, and Claudia Olivetti. 2004. "Mothers and Sons: Preference Formation and Female Labor Force Dynamics," Quarterly Journal of Economics 119 (November): 1249-99.

Goldin, Claudia. 1991. "Marriage Bars: Discrimination against Married Women from the 1920s to the 1950s." In H. Rosovsky, D. Landes, and P. Higonnet, eds., Favorites of Fortune: Technology, Growth and Economic Development since the Industrial Revolution. Cambridge, MA: Harvard University Press, pp. 511-36.

Goldin, Claudia. 1997. "Career and Family: College Women Look to the Past." In F. Blau and R. Ehrenberg, eds., Gender and Family Issues in the Workplace. New York: Russell Sage Press, pp. 20-58.

Goldin, Claudia. 1998. "America's Graduation from High School: The Evolution and Spread of Secondary Schooling in the Twentieth Century," Journal of Economic History 58 (June): 345-74.

Goldin, Claudia. 2005. "From the Valley to the Summit: A Brief History of the Quiet Revolution that Transformed Women's Work," Regional Review, Q1 vol. 14: 5-12.

Goldin, Claudia, and Lawrence F. Katz. 2002. "The Power of the Pill: Oral Contraceptives and Women's Career and Marriage Decisions," Journal of Political Economy 110 (August): 73070 .

Hock, Heinrich. 2004. "The Pill and the Educational Attainment of American Women and Men." Brown University, unpublished paper (November).

Jacob, Brian A. 2002. "Where the Boys Aren't: Non-cognitive Skills, Returns to School and the Gender Gap in Higher Education," Economics of Education Review 21 (December): 589-98.

Katz, Lawrence F. and Kevin M. Murphy. 1992. "Changes in Relative Wages, 1963-87: Supply and Demand Factors," Quarterly Journal of Economics 107 (February): 35-78.

Long, Bridget Terry. 2005. "The Reversal of the College Gender Gap: How Have Women Surpassed Men?" Harvard University, Graduate School of Education, unpublished paper (January).

Silverman, Irwin W. 2003. "Gender Differences in Delay of Gratification: A Meta-Analysis," Sex Roles 49 (November): 451-63. 
Stanley, Marcus. 2003. "College Education and the Midcentury GI Bills," Quarterly Journal of Economics 118 (May): 671-708.

U.S. Department of Education. 2004. Digest of Education Statistics, 2003. Washington, D.C.: National Center for Education Statistics, Institute of Education Sciences.

U.S. Department of Education. 2005. Digest of Education Statistics, 2004. Washington, D.C.: National Center for Education Statistics, Institute of Education Sciences.

U.S. Office of Education. [various years to 1917.] Report of the Commissioner of Education for (various years to 1917). Washington, D.C.: G.P.O.

Note: We refer to this source as the Annual Reports.

U.S. Office [Bureau] of Education. [various years from 1916-18 to 1956-58.] Biennial Survey of Education for (various years from 1916-18 to 1956-58). Washington, D.C.: G.P.O. Notes: We refer to this source as the Biennial Reports. After 1953, the Office of Education was housed in the Department of Health, Education and Welfare.

U.S. Office of Education. [various years from 1958.] Opening Fall Enrollments. (various years from 1958 to 1968). Washington, D.C.: G.P.O. Notes: We refer to this source as Opening Fall Enrollments. After 1953, the Office of Education was housed in the Department of Health, Education and Welfare. NCES took over the series in 1965 .

Wirt, J., S. Choy, P. Rooney, S. Provasnik, A. Sen, and R. Tobin. 2004. The Condition of Education 2004. U.S. Department of Education. National Center for Education Statistics. Washington, D.C.: U.S. Government Printing Office. 
Figure 1

College Graduation Rates (by 35 years) for Men and Women: Cohorts Born from 1876 to 1975

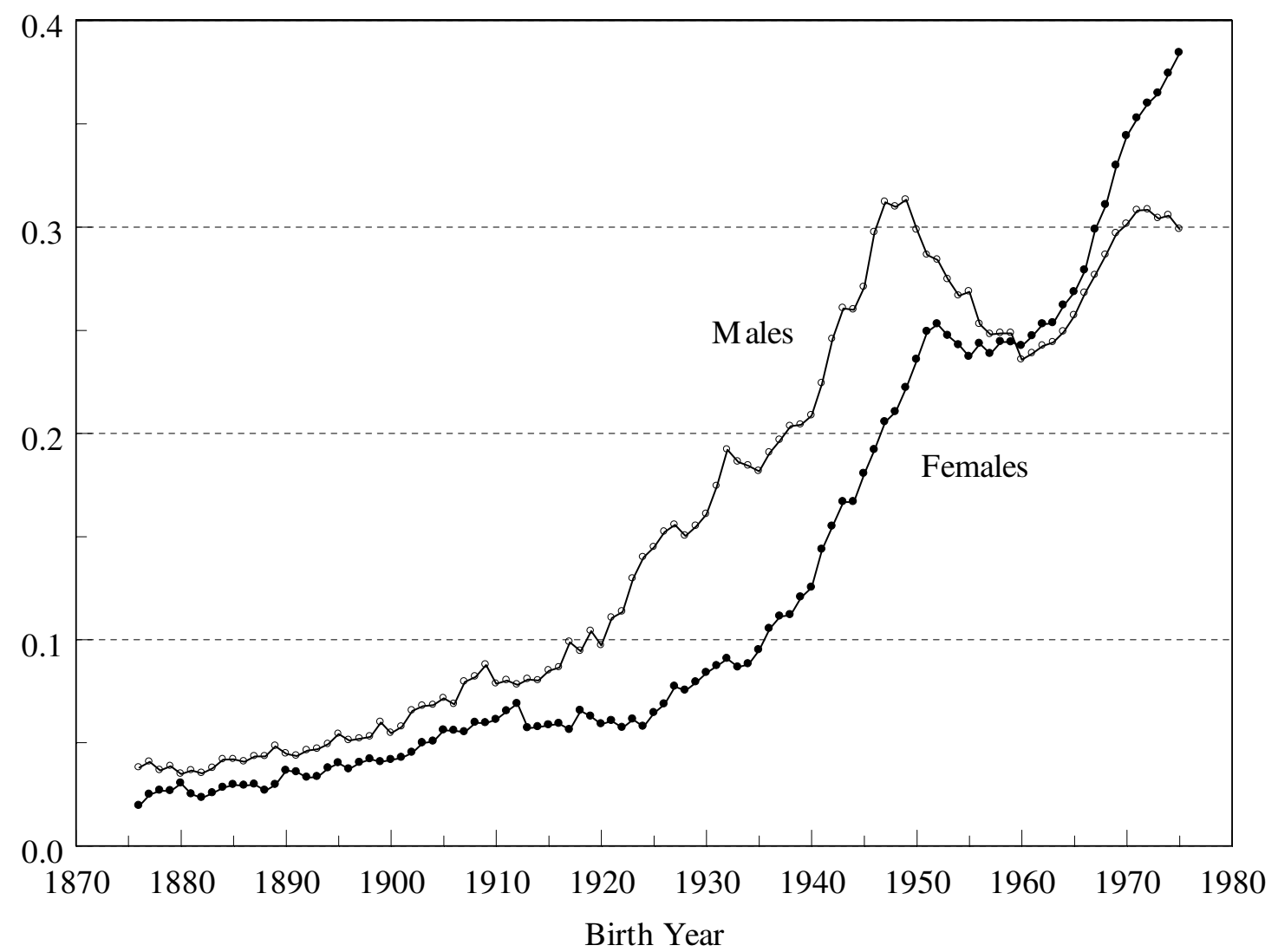

Sources: 1940 to 2000 Census of Population Integrated Public Use Micro-data Samples (IPUMS).

Notes: The figure plots the fraction of four-year college graduates by birth cohort and sex adjusted to 35 years of age for the U.S. born. College graduates are those with 16 or more completed years of schooling for the 1940 to 1980 samples and those with a bachelor's degree or higher in the 1990 to 2000 samples. The log of the college graduation rate for a birth cohort-year cell is the dependent variable in the age-adjustment regressions that include a full set of birthcohort dummies and a quartic in age as covariates. The age-adjustment regressions are run on birth cohort-census year cells, pooling all the IPUMS for 1940 to 2000. The underlying samples include all U.S. born residents aged 25 to 64 years. For more details on the method, see De Long, Goldin, and Katz (2003), notes to figure 1. 
Figure 2

Ratio of Male to Female College Rates: Birth Cohorts from 1876 to 1975

(three-year centered moving averages measured at 35 years of age)

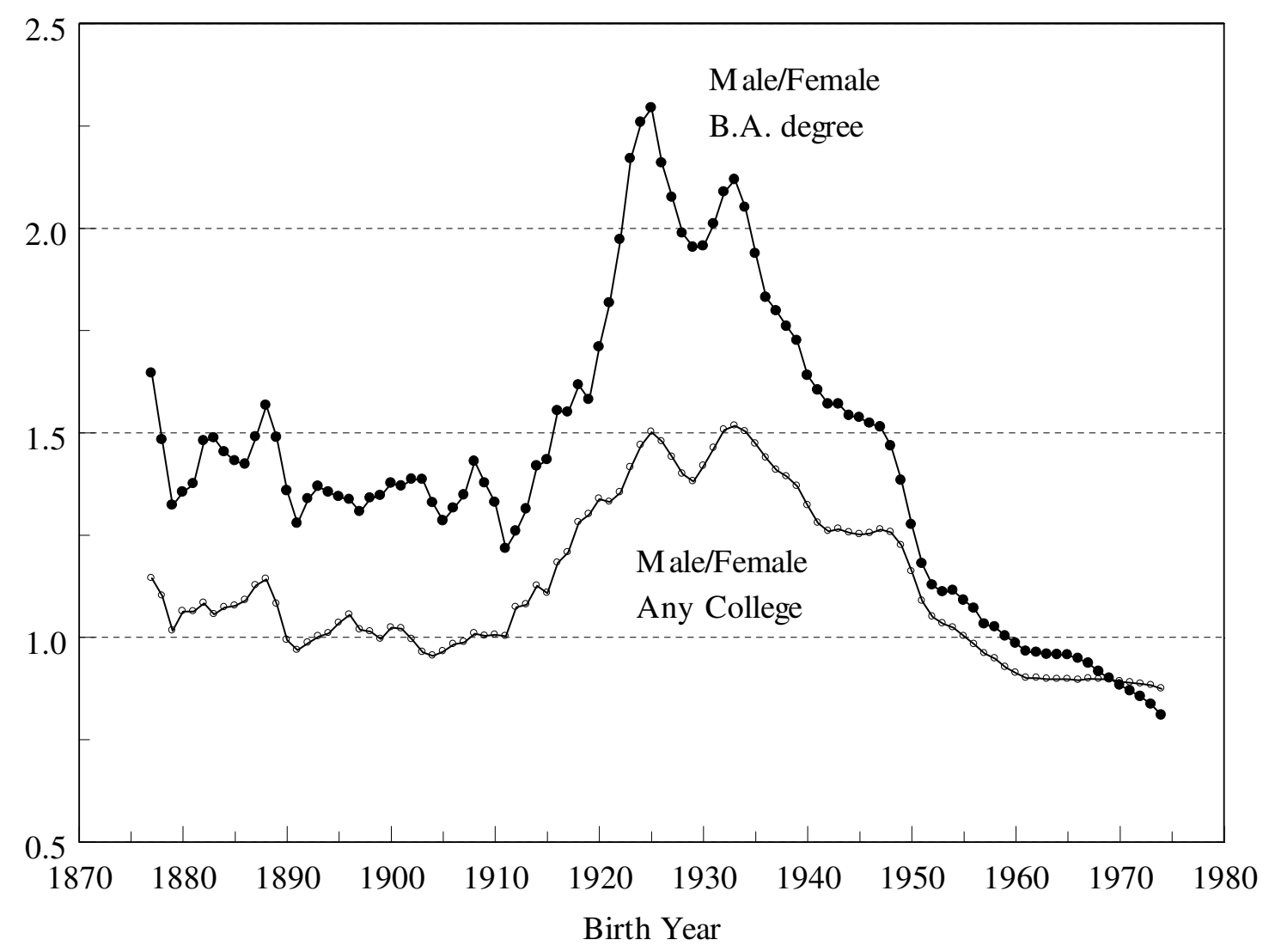

Sources and Notes: 1940 to 2000 Census of Population Integrated Public Use Micro-data Samples (IPUMS). College graduates are those with 16 or more completed years of schooling for the 1940 to 1980 samples and those with a bachelor's degree or higher in the 1990 to 2000 samples. Any college includes those with 13 or more years of school attended in the 1940 to 1980 samples and those with some college or more in the 1990 to 2000 samples. See the notes to Figure 1 for details on the age-adjustment methodology for college graduates. The same approach is used for any college. 
Figure 3

Difference between Male and Female College Rates: Birth Cohorts from 1876 to 1975 (three-year centered moving averages measured at 35 years of age)

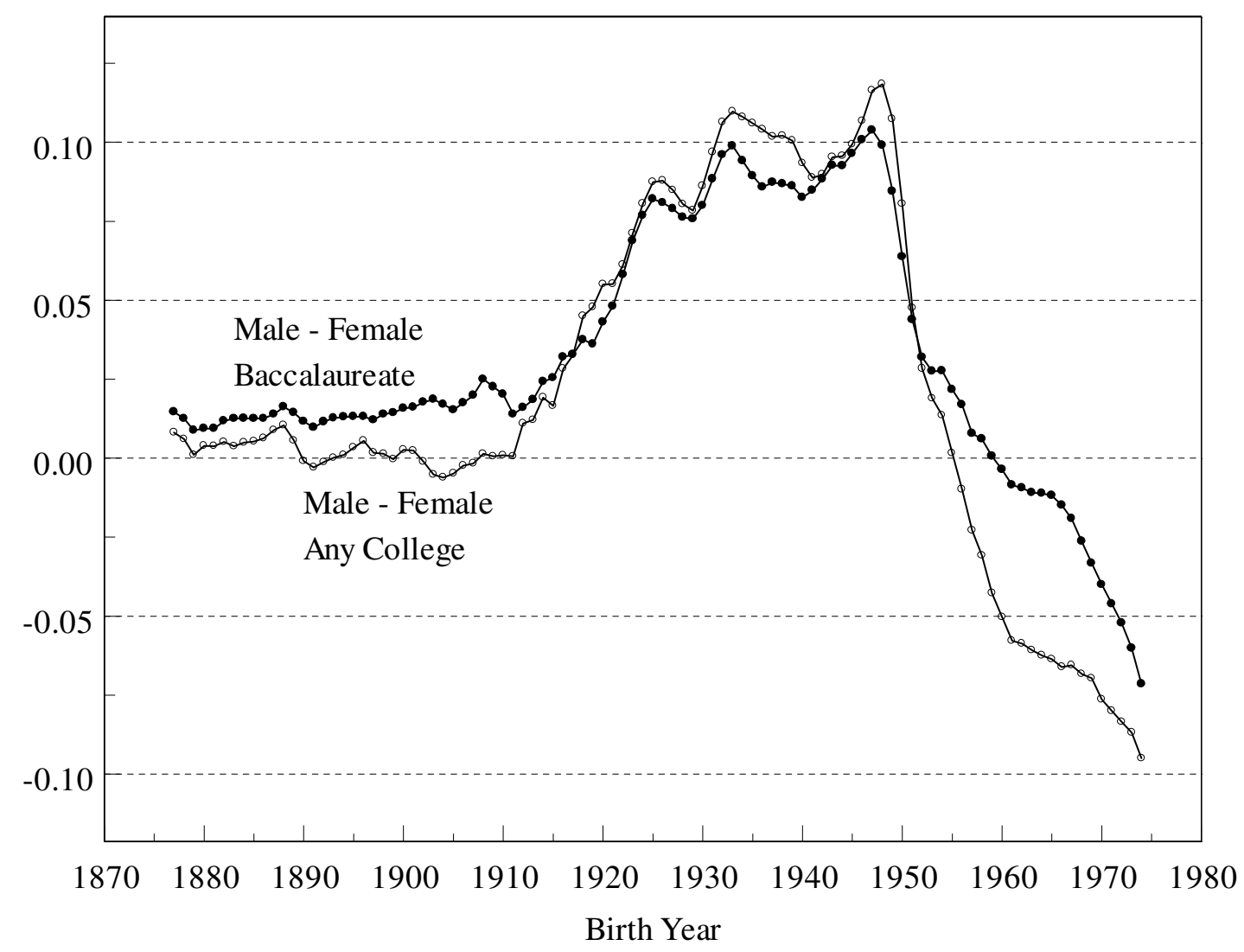

Sources and Notes: See Figure 2. 
Figure 4

Ratios of Males to Females with Any College by Cohort and Year (Contemporaneous): Census (plus 20 years) and Administrative Data

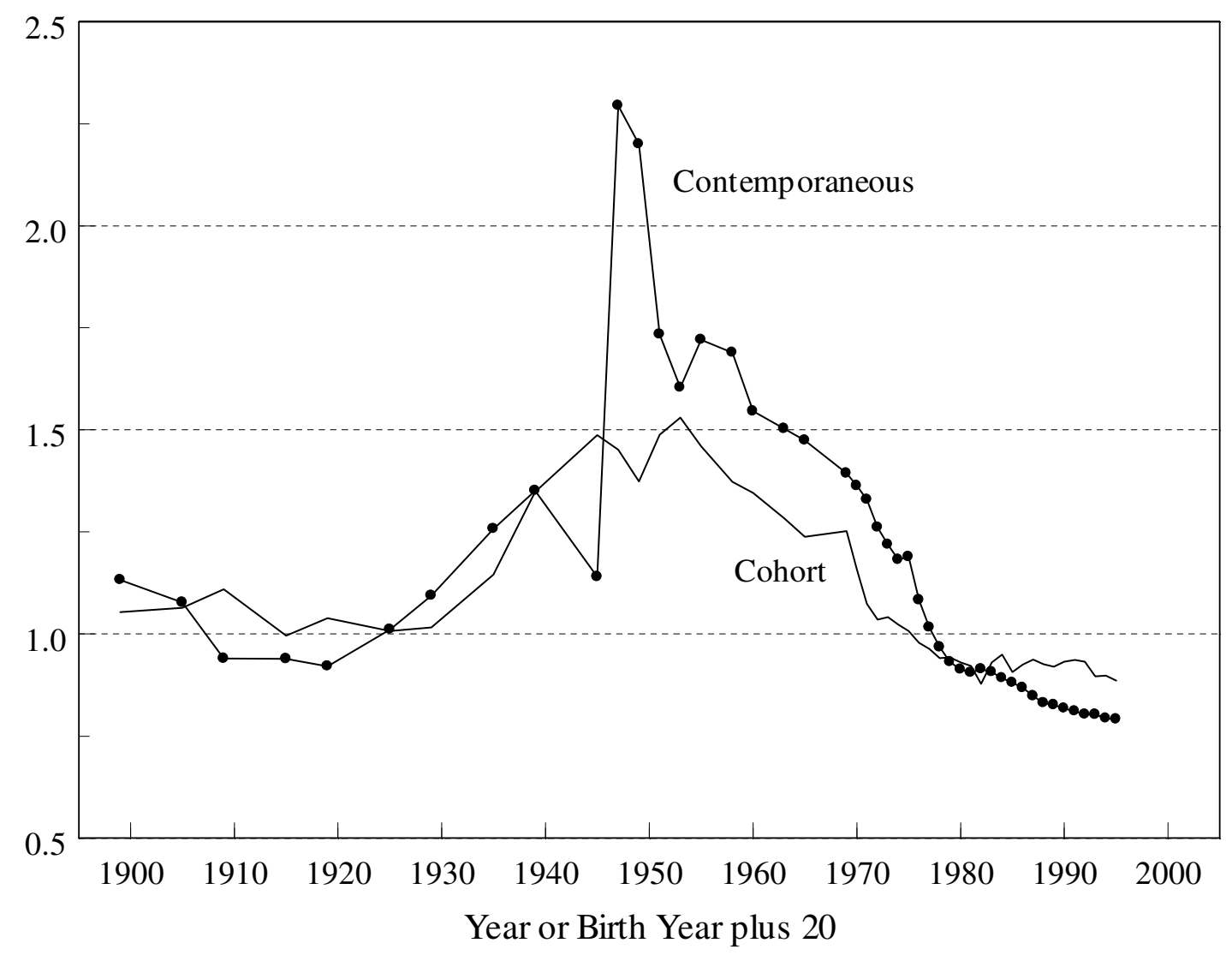

Notes and Sources: Cohort: see Figures 1 and 2. Contemporaneous: U.S. Office of Education, Annual Reports, Biennial Reports; Opening Fall Enrollments. Enrollment before 1946 was asked at the end of the year. After 1946 enrollment was asked at the start of the Fall term. Duplicates have been removed. Graduate and professional students are omitted from the undergraduate totals as are preparatory students in college. In the case of professional students, some may have been pursuing their first degrees, thus their omission understates the number of undergraduates, particularly men. Data for teaching and normal (college) schools exclude those attending only summer sessions. Students attending normal schools were generally enrolled in teacher training, but sometimes not. Up to and including 1930, only the data for the teacher training students were reported. The omission probably understates total enrollment by at most 10 percent. The 1930 number is understated by at most 5 percent. The data to 1955/56 are for "resident college enrollment," that is individuals registered for a degree. Beginning in 1963 schools also reported non-degree enrollment and separated the enrollment into full-time and parttime. The data given here are for full-time and part-time, but it is not clear what part-time enrollment was relative to the total in the pre-1963 period. Summer session enrollment is not included for any of the groups, and the same is true for enrollment in extension schools and correspondence courses. 
Figure 5

International Comparisons of Tertiary School Enrollments by Sex: 1985 and 2002

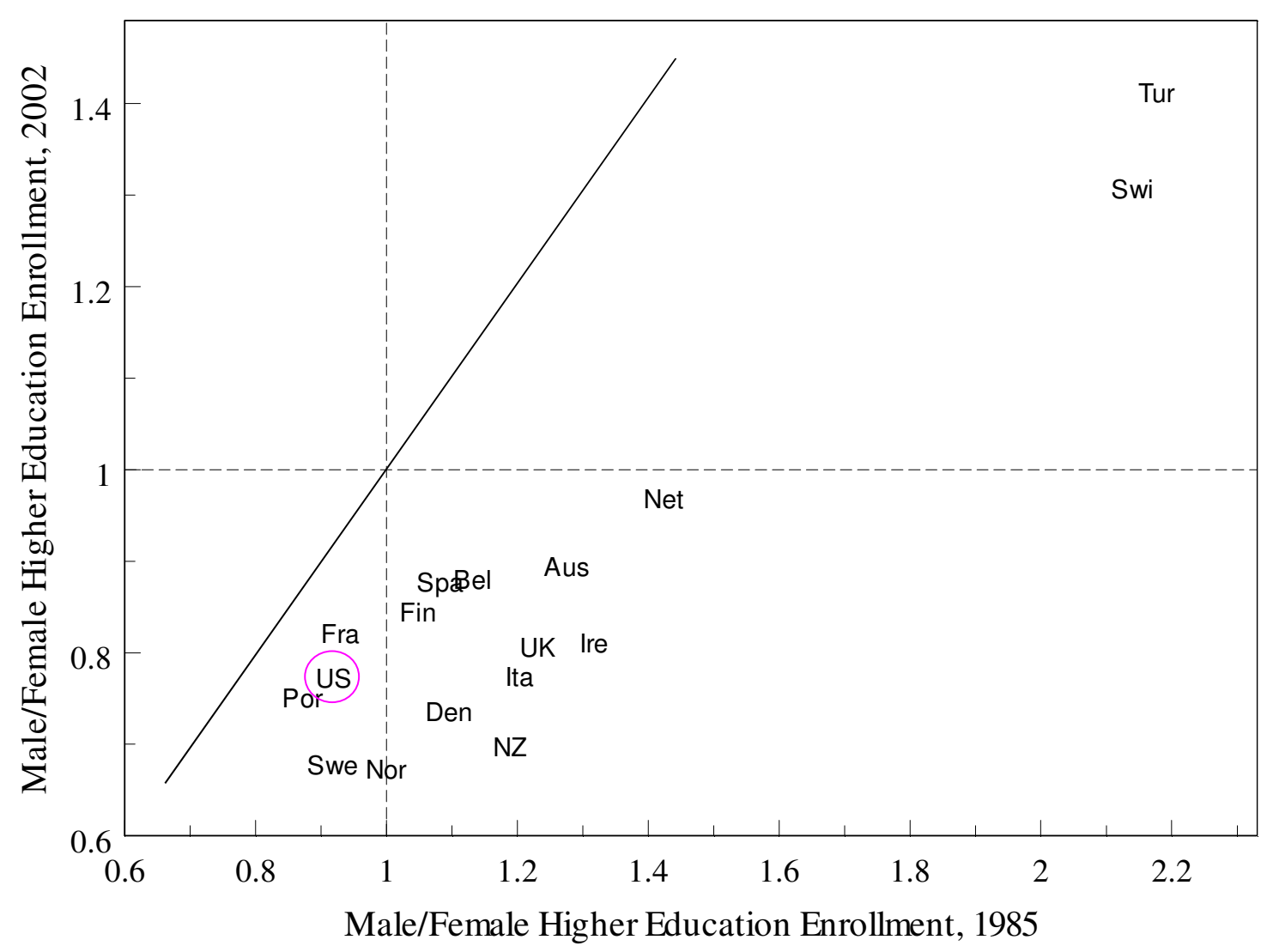

Source: OECD Education Online Database, http://www.oecd.org .

Notes: Enrollment data are for all individuals in tertiary education, part-time and full-time, including both two-year and four-year colleges but excluding vocational and industrial postsecondary school training. 
Figure 6

Ratio of Female to Male College Completion by Socio-Economic Status for High School

Seniors: 1957, 1972, and 1992 for Whites

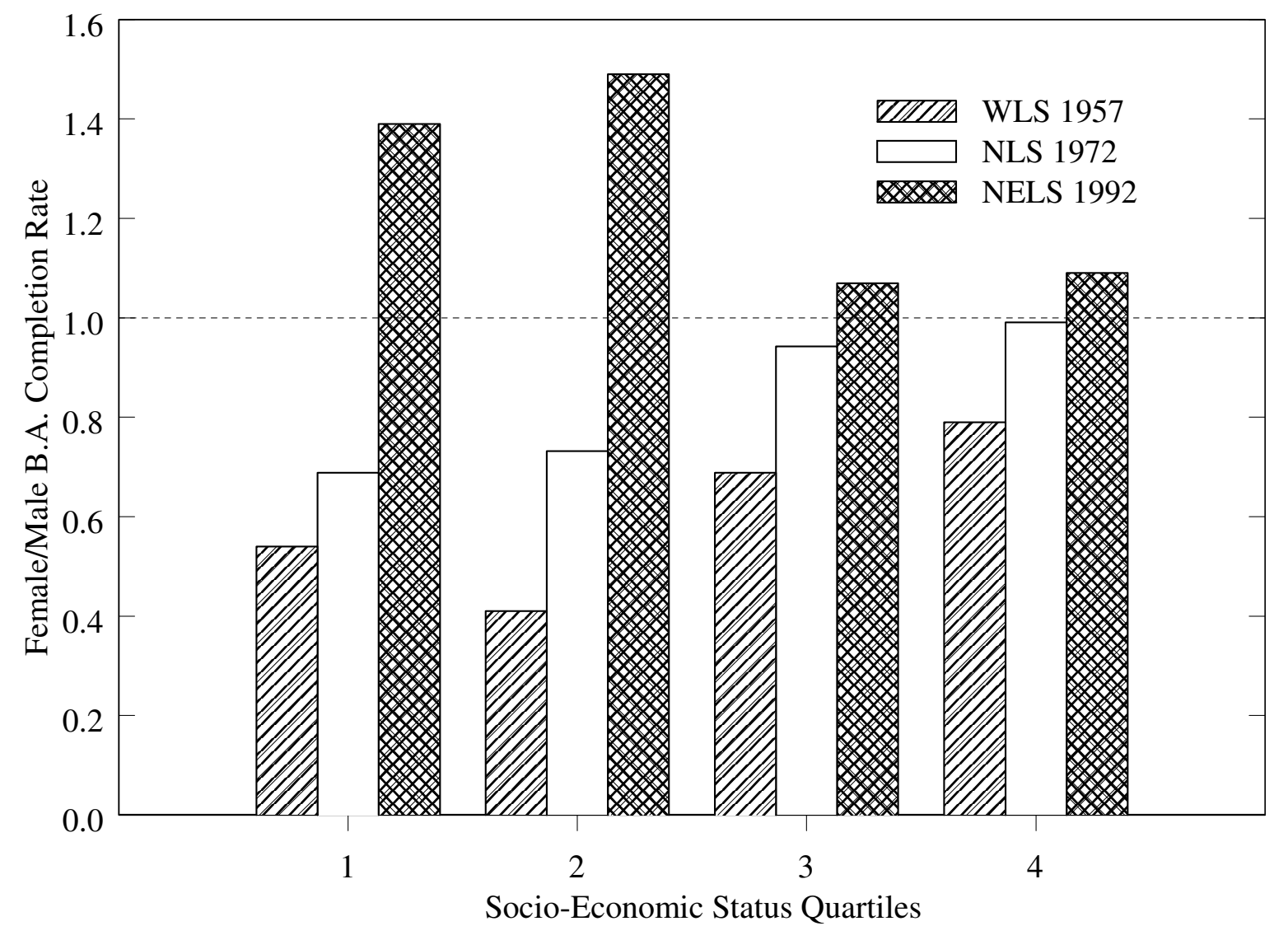

Sources: Table 8, Panel A. 
Figure 7

Expectations and Opinions of Female Teenagers and College Freshmen: 1967 to 1984

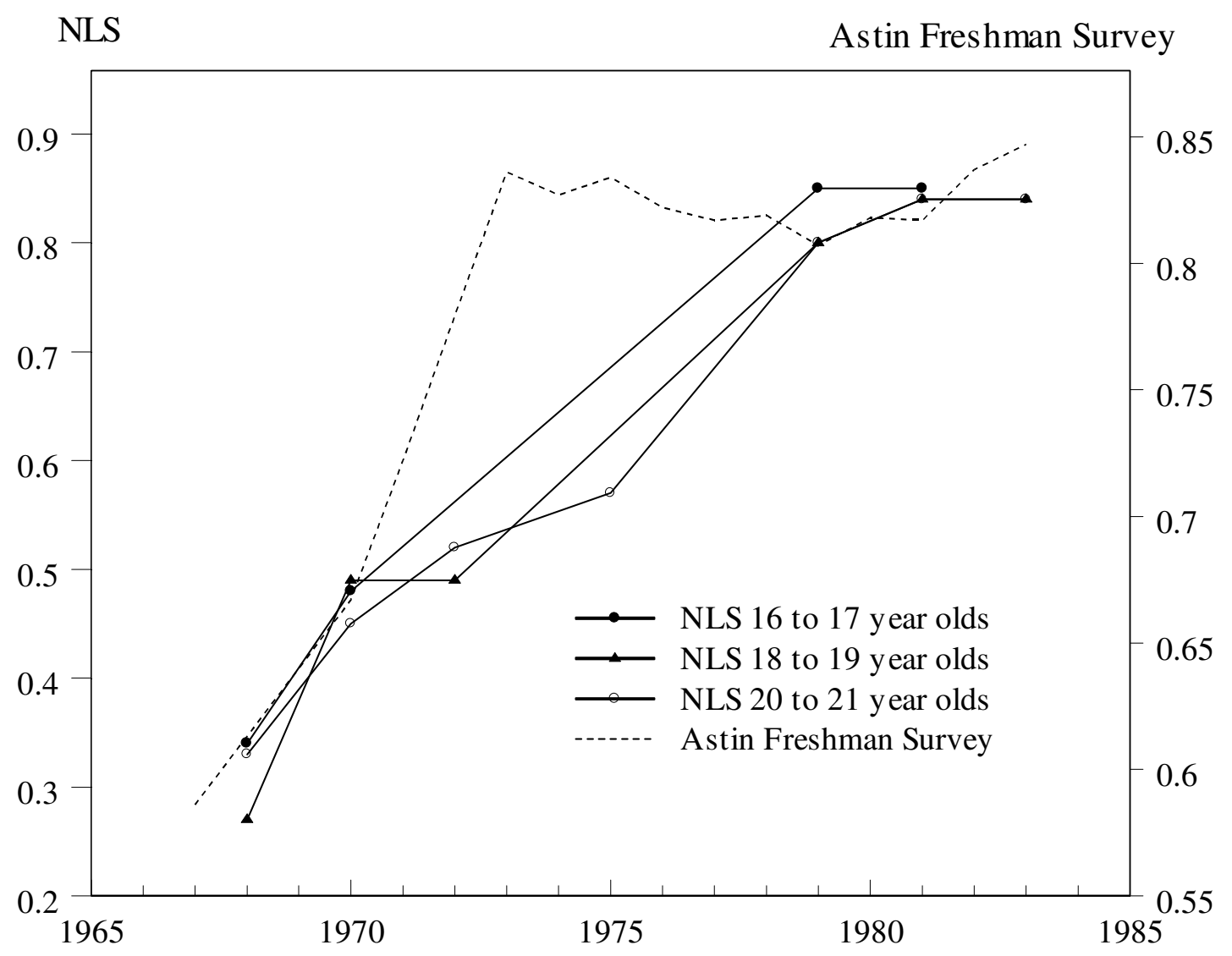

Sources: Goldin (2005), which uses the 1968 National Longitudinal Survey of Young Women (NLS68) and 1979 National Longitudinal Survey of Youth (NLSY); Astin, et al. (2002).

Notes: The NLS data are the response to whether an individual stated she expected to be in the paid labor force at age 35 and are given here for white women. The Astin Freshman Survey data are the response to whether the individual disagreed with the statement "the activities of married women are best confined to the home and family." The NLS data link the averages for each age group over time. Thus, the 14 to 15 year olds in the NLS68 in 1968 became 16 to 17 years old in 1970 and are linked to the 16 to 17 year olds in 1979 in the NLSY79. The Astin, et al. data are for college freshman; about 84 percent of these freshmen were 18 years old in 1967 (on December 31) and 80 percent were in 1984 (on December 31). 
Table 1: WLS, High School Graduating Class of 1957

Part A: IQ and High School Rank Deciles by Sex

\begin{tabular}{ccccccc}
\hline \hline & & & & High School & \\
IQ Decile & Male & Female & & Rank Deciles & Male & Female \\
\cline { 1 - 3 } \cline { 5 - 6 } 1 & 0.106 & 0.0945 & & 0 & 0.141 & 0.0617 \\
2 & 0.0970 & 0.103 & & 1 & 0.131 & 0.0705 \\
3 & 0.0952 & 0.104 & & 2 & 0.122 & 0.0789 \\
4 & 0.101 & 0.0991 & & 3 & 0.111 & 0.0900 \\
5 & 0.0956 & 0.104 & & 4 & 0.107 & 0.0932 \\
6 & 0.0950 & 0.105 & & 5 & 0.0967 & 0.103 \\
7 & 0.105 & 0.0949 & & 6 & 0.0827 & 0.116 \\
8 & 0.0946 & 0.105 & & 7 & 0.0802 & 0.118 \\
9 & 0.104 & 0.0959 & & 8 & 0.0684 & 0.130 \\
Median & 0.106 & 0.0942 & & 9 & 0.0601 & 0.138 \\
Percentile & 50.7 & 49.4 & & Median & 39.7 & 60.2 \\
\hline \hline
\end{tabular}

Part B: Obtain B.A. by IQ Decile, HS Class Rank Decile, and Sex

\begin{tabular}{|c|c|c|c|c|c|}
\hline \multirow[b]{2}{*}{ IQ Decile } & \multicolumn{2}{|c|}{ B.A. Degree } & \multirow[b]{2}{*}{$\begin{array}{c}\text { HS Rank } \\
\text { Decile }\end{array}$} & \multicolumn{2}{|c|}{ B.A. Degree } \\
\hline & Male & Female & & Male & Female \\
\hline 0 & 0.0153 & 0.00965 & 0 & 0.0200 & 0.00376 \\
\hline 1 & 0.0318 & 0.0201 & 1 & 0.0336 & 0.0132 \\
\hline 2 & 0.0783 & 0.0333 & 2 & 0.0712 & 0.0263 \\
\hline 3 & 0.105 & 0.0647 & 3 & 0.0804 & 0.0440 \\
\hline 4 & 0.153 & 0.0971 & 4 & 0.194 & 0.0606 \\
\hline 5 & 0.200 & 0.154 & 5 & 0.265 & 0.109 \\
\hline 6 & 0.251 & 0.145 & 6 & 0.319 & 0.0838 \\
\hline 7 & 0.305 & 0.236 & 7 & 0.387 & 0.152 \\
\hline 8 & 0.431 & 0.275 & 8 & 0.585 & 0.249 \\
\hline 9 & 0.560 & 0.427 & 9 & 0.810 & 0.425 \\
\hline
\end{tabular}

Source: WLS (Wisconsin Longitudinal Survey 1957).

Notes: The means and number of observations for the tabulation samples are:

Obtain BA by 1964:

Number of observations
IQ Test

Males Females

High School Rank

Males Females

$\begin{array}{llll}0.216 & 0.144 & 0.217 & 0.143\end{array}$

$4,379 \quad 4,609 \quad 4,071 \quad 4,309$

The sample includes those who responded to the 1964 follow-up survey. Deciles for each variable are based on the entire (male and female) sample for those who gave a valid response for that variable. "Obtain B.A." means to have graduated from a four-year college by 1964. 
Table 2: NLS, High School Graduating Class of 1972

Part A: Reading and Math Test Score and High School Rank Deciles by Sex ${ }^{a}$

\begin{tabular}{|c|c|c|c|c|c|c|c|c|}
\hline \multirow{2}{*}{$\begin{array}{l}\text { De- } \\
\text { cile }\end{array}$} & \multicolumn{2}{|c|}{ Composite $^{b}$} & \multicolumn{2}{|c|}{ Reading } & \multicolumn{2}{|c|}{ Math } & \multicolumn{2}{|c|}{ HS Rank } \\
\hline & Males & Females & Males & Females & Males & Females & Males & Females \\
\hline 0 & 0.0947 & 0.105 & 0.109 & 0.0918 & 0.0815 & 0.118 & 0.136 & 0.0651 \\
\hline 1 & 0.0855 & 0.114 & 0.0976 & 0.102 & 0.0901 & 0.110 & 0.125 & 0.0754 \\
\hline 2 & 0.1050 & 0.0951 & 0.0985 & 0.102 & 0.0866 & 0.113 & 0.115 & 0.0849 \\
\hline 3 & 0.0876 & 0.112 & 0.0958 & 0.104 & 0.0934 & 0.106 & 0.110 & 0.0905 \\
\hline 4 & 0.0933 & 0.107 & 0.0987 & 0.101 & 0.0934 & 0.107 & 0.104 & 0.0959 \\
\hline 5 & 0.106 & 0.0946 & 0.104 & 0.0963 & 0.101 & 0.100 & 0.0950 & 0.105 \\
\hline 6 & 0.104 & 0.0964 & 0.102 & 0.0977 & 0.0972 & 0.103 & 0.0909 & 0.109 \\
\hline 7 & 0.103 & 0.0972 & 0.101 & 0.0994 & 0.108 & 0.0921 & 0.0767 & 0.123 \\
\hline 8 & 0.107 & 0.934 & 0.100 & 0.100 & 0.117 & 0.0833 & 0.0747 & 0.125 \\
\hline 9 & 0.115 & 0.0855 & 0.0941 & 0.106 & 0.132 & 0.0687 & 0.0723 & 0.127 \\
\hline $\begin{array}{l}\text { Med. } \\
\text { Perc. }\end{array}$ & 53.4 & 46.9 & 50.1 & 49.8 & 55.7 & 44.8 & 41.3 & 58.4 \\
\hline
\end{tabular}

Part B: Obtain B.A. by Composite Score Decile, High School Class Rank Decile, and Sex

\begin{tabular}{|c|c|c|c|c|c|}
\hline \multirow{2}{*}{$\begin{array}{l}\text { Composite } \\
\text { Reading and } \\
\text { Math Deciles }\end{array}$} & \multicolumn{2}{|c|}{ B.A. Degree } & \multirow[b]{2}{*}{$\begin{array}{l}\text { High School } \\
\text { Grade Deciles }\end{array}$} & \multicolumn{2}{|c|}{ B.A. Degree } \\
\hline & Male & Female & & Male & Female \\
\hline 0 & 0.0224 & 0.0254 & 0 & 0.0402 & 0.0338 \\
\hline 1 & 0.0565 & 0.0545 & 1 & 0.108 & 0.0591 \\
\hline 2 & 0.0786 & 0.0869 & 2 & 0.131 & 0.0866 \\
\hline 3 & 0.148 & 0.139 & 3 & 0.197 & 0.116 \\
\hline 4 & 0.204 & 0.179 & 4 & 0.234 & 0.138 \\
\hline 5 & 0.241 & 0.247 & 5 & 0.375 & 0.213 \\
\hline 6 & 0.381 & 0.327 & 6 & 0.422 & 0.242 \\
\hline 7 & 0.439 & 0.433 & 7 & 0.501 & 0.304 \\
\hline 8 & 0.541 & 0.503 & 8 & 0.615 & 0.423 \\
\hline 9 & 0.668 & 0.681 & 9 & 0.778 & 0.627 \\
\hline
\end{tabular}

${ }^{a} \mathrm{We}$ computed the deciles by randomizing individuals around the breaks to get around the problem of heaping since the aptitude tests included fewer than 30 questions,

'The "composite" aptitude score is a simple average of the twelfth grade reading and math scores for comparability with the WLS which includes only IQ.

Source: NLS (National Longitudinal Survey 1972).

Notes: The weighted means and number of observations for the tabulation samples are:

Obtain BA:

Test Scores

Males Females

High School Rank

Males Females

Number of observations:

$\begin{array}{ll}0.292 & 0.254 \\ 4,828 & 5,277\end{array}$

$0.295 \quad 0.256$

$4,828 \quad 5,277 \quad 4,712 \quad 5,131$

Sample weights are used. The sample includes those who from graduated high school by 1974 and were present in the fourth NLS follow-up in 1979. "Obtain B.A." means to have graduated from a four-year college by 1979. Deciles are based on the entire (male and female) sample. 
Table 3: NELS, High School Graduating Class of 1992

Part A: Composite, Reading, and Math Test Score and High School Rank Deciles by Sex

\begin{tabular}{|c|c|c|c|c|c|c|c|c|}
\hline \multirow{2}{*}{$\begin{array}{l}\text { De- } \\
\text { cile }\end{array}$} & \multicolumn{2}{|c|}{ Composite } & \multicolumn{2}{|c|}{ Reading } & \multicolumn{2}{|c|}{ Math } & \multicolumn{2}{|c|}{ HS Rank } \\
\hline & Males & Females & Males & Females & Males & Females & Males & Females \\
\hline 0 & 0.106 & 0.0946 & 0.121 & 0.0791 & 0.0881 & 0.112 & 0.130 & 0.0696 \\
\hline 1 & 0.113 & 0.0889 & 0.119 & 0.0808 & 0.113 & 0.0872 & 0.120 & 0.0788 \\
\hline 2 & 0.0993 & 0.0992 & 0.105 & 0.0955 & 0.0843 & 0.115 & 0.120 & 0.0797 \\
\hline 3 & 0.102 & 0.0980 & 0.0990 & 0.101 & 0.0981 & 0.103 & 0.108 & 0.0921 \\
\hline 4 & 0.0920 & 0.108 & 0.0911 & 0.109 & 0.0960 & 0.103 & 0.100 & 0.0996 \\
\hline 5 & 0.0904 & 0.109 & 0.0931 & 0.109 & 0.0907 & 0.109 & 0.0937 & 0.107 \\
\hline 6 & 0.0917 & 0.108 & 0.0954 & 0.106 & 0.105 & 0.0961 & 0.0800 & 0.121 \\
\hline 7 & 0.104 & 0.0964 & 0.0886 & 0.108 & 0.0982 & 0.101 & 0.0859 & 0.115 \\
\hline 8 & 0.964 & 0.103 & 0.103 & 0.100 & 0.108 & 0.0923 & 0.0797 & 0.120 \\
\hline 9 & 0.105 & 0.0946 & 0.0875 & 0.112 & 0.119 & 0.0808 & 0.0822 & 0.118 \\
\hline $\begin{array}{l}\text { Med. } \\
\text { Perc. }\end{array}$ & 49.0 & 51.0 & 46.6 & 53.5 & 53.2 & 48.3 & 42.1 & 57.8 \\
\hline
\end{tabular}

Part B: Obtain B.A. by Composite Test Score Decile, High School Class Rank Decile, and Sex

\begin{tabular}{ccccccc}
\hline \hline $\begin{array}{c}\text { Composite } \\
\text { Reading and } \\
\text { Math Deciles }\end{array}$ & \multicolumn{2}{c}{ B.A. Degree } & & \multicolumn{2}{c}{ B.A. Degree } \\
& & Female & & $\begin{array}{c}\text { High School } \\
\text { Grade Deciles }\end{array}$ & Male & Female \\
\cline { 1 - 2 } \cline { 5 - 7 } & 0.0895 & 0.0639 & & 0 & 0.0562 & 0.0498 \\
2 & 0.229 & 0.182 & & 1 & 0.145 & 0.0990 \\
3 & 0.171 & 0.199 & & 2 & 0.184 & 0.163 \\
4 & 0.301 & 0.265 & & 3 & 0.232 & 0.210 \\
5 & 0.370 & 0.325 & & 4 & 0.314 & 0.209 \\
6 & 0.347 & 0.393 & & 5 & 0.394 & 0.353 \\
7 & 0.399 & 0.538 & & 6 & 0.424 & 0.495 \\
8 & 0.465 & 0.613 & & 7 & 0.582 & 0.579 \\
9 & 0.540 & 0.671 & & 8 & 0.624 & 0.714 \\
\hline \hline
\end{tabular}

Source: NELS (National Educational Longitudinal Survey 1988, restricted-access sample).

Notes: The weighted means and number of observations for the tabulation samples are:

\begin{tabular}{|c|c|c|c|}
\hline Test $\mathrm{S}$ & cores & High & chool Rank \\
\hline Males & Females & Males & Females \\
\hline 0.349 & 0.420 & 0.338 & 0.417 \\
\hline 3,751 & 4,193 & 3,642 & 4,037 \\
\hline
\end{tabular}

Obtain BA:

$3,751 \quad 4,193$

Number of observations:

udes on-time high school graduates of the class of 1992 who were present in the 2000 follow-up survey. Test score deciles are based on the entire (male and female) sample with non-missing data for $12^{\text {th }}$ grade math and reading test scores. The composite test score is the average of the math and reading normalized test scores. High School rank deciles are based on the entire sample with non-missing high school rank data. "Obtain B.A." means to have graduated from a four-year college by 2000. 
Table 4: Courses Taken by High School Graduates: 1957 to 1992

\begin{tabular}{|c|c|c|c|c|c|c|c|c|c|c|c|c|}
\hline & \multicolumn{6}{|c|}{ Semesters $^{\mathrm{a}}$} & \multicolumn{6}{|c|}{ Carnegie Units ${ }^{a}$} \\
\hline & \multicolumn{3}{|c|}{$\begin{array}{l}1957 \text { Graduates } \\
\text { WLS }\end{array}$} & \multicolumn{3}{|c|}{$\begin{array}{c}1972 \text { Graduates } \\
\text { NLS }\end{array}$} & \multicolumn{3}{|c|}{1982 Graduates } & \multicolumn{3}{|c|}{$\begin{array}{c}1992 \text { Graduates } \\
\text { NELS }\end{array}$} \\
\hline & Males & Female & $\mathrm{M} / \mathrm{F}$ & Males & Females & $\mathrm{M} / \mathrm{F}$ & Males & Females & $\mathrm{M} / \mathrm{F}$ & Males & Females & $\mathrm{M} / \mathrm{F}$ \\
\hline Total academic & 22.79 & 21.30 & 1.07 & 21.61 & 20.52 & 1.05 & 12.82 & 13.00 & 0.99 & 15.17 & 15.76 & 0.96 \\
\hline Math & 4.02 & 2.89 & 1.39 & 4.18 & 3.36 & 1.24 & 2.71 & 2.57 & 1.06 & 3.22 & 3.22 & 1.00 \\
\hline Algebra & 2.27 & 1.78 & 1.27 & & & & & & & 1.55 & 1.59 & 0.97 \\
\hline Geometry & 1.46 & 1.05 & 1.39 & & & & & & & 0.74 & 0.76 & 0.97 \\
\hline Trigonometry & 0.29 & 0.063 & 4.57 & & & & & & & 0.18 & 0.17 & 1.04 \\
\hline Science $^{\mathrm{b}}$ & 3.76 & 2.90 & 1.30 & 3.82 & 3.18 & 1.20 & 2.27 & 2.13 & 1.07 & 2.99 & 2.94 & 1.02 \\
\hline Biology & 1.62 & 1.73 & 0.93 & & & & 0.91 & 0.97 & 0.94 & 1.14 & 1.23 & 0.93 \\
\hline Chemistry & 1.14 & 0.87 & 1.32 & & & & 0.36 & 0.33 & 1.09 & 0.63 & 0.65 & 0.97 \\
\hline Physics & 1.01 & 0.30 & 3.39 & & & & 0.23 & 0.12 & 1.92 & 0.33 & 0.23 & 1.43 \\
\hline Foreign lang. & 1.25 & 1.72 & 0.73 & 1.87 & 2.36 & 0.79 & 0.80 & 1.17 & 0.68 & 1.55 & 1.99 & 0.78 \\
\hline Social studies ${ }^{c}$ & 6.42 & 6.28 & 1.02 & 5.48 & 5.35 & 1.02 & 3.16 & 3.15 & 1.00 & 3.39 & 3.50 & 0.97 \\
\hline English & 7.33 & 7.50 & 0.98 & 6.27 & 6.26 & 1.00 & 3.88 & 3.98 & 0.97 & 4.02 & 4.12 & 0.98 \\
\hline
\end{tabular}

${ }^{a}$ The WLS and the NLS measure actual semesters, although the total number of semesters in the WLS may be understated somewhat by the absence of "other" academic subjects within the major categories. The NELS measures courses in Carnegie units, which are a standard of measurement that allots one credit for each one-year (full-time equivalent) course completed.

${ }^{\mathrm{b}}$ Separate subjects do not sum to total.

${ }^{\mathrm{c}}$ Social studies includes history.

Sources: WLS for 1957, NLS for 1972, NELS for 1992. U.S. Department of Education (2004), Table 137 for 1982.

Notes: Only academic courses are listed. Semesters or units, depending on the study used, are not comparable across surveys. WLS: Missing values for courses are coded as zero. Only students with more than 12 total academic courses as seniors are counted. The restriction eliminates just 9 percent of all seniors in the survey. The resulting sample contains 4,545 males and 4,843 females. Data are from student self-reports. NLS: Missing values for courses are coded as zero. Only students with more than six total academic courses as seniors were counted. The restriction eliminates less than 2 percent of all seniors in the survey. The resulting sample contains 4,519 males and 4,878 females. Course data were extracted from high school records. NELS: Observations with missing values for courses are deleted. The sample contains 4,120 males and 4,593 females. Data are from transcript records. 
Table 5: Determinants of College Completion among High School Graduates: 1957 and 1972

\begin{tabular}{|c|c|c|c|c|c|}
\hline "WLS: 1957 graduates & $\overline{(1)}$ & 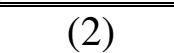 & 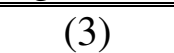 & 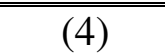 & $\overline{(5)}$ \\
\hline Female & $\begin{array}{c}-0.075 \\
(0.0083)\end{array}$ & $\begin{array}{c}-0.067 \\
(0.0080)\end{array}$ & $\begin{array}{c}-0.067 \\
(0.0075)\end{array}$ & $\begin{array}{c}-0.128 \\
(0.0077)\end{array}$ & $\begin{array}{c}-0.075 \\
(0.0081)\end{array}$ \\
\hline IQ score & & & $\begin{array}{c}0.121 \\
(0.0039)\end{array}$ & $\begin{array}{c}0.051 \\
(0.0047)\end{array}$ & $\begin{array}{c}0.029 \\
(0.0048)\end{array}$ \\
\hline HS rank percentile/100 & & & & $\begin{array}{c}0.413 \\
(0.017)\end{array}$ & $\begin{array}{c}0.329 \\
(0.017)\end{array}$ \\
\hline \multicolumn{6}{|l|}{ Courses (semesters) } \\
\hline Math & & & & & $\begin{array}{c}0.029 \\
(0.0021)\end{array}$ \\
\hline Science & & & & & $\begin{array}{c}0.016 \\
(0.0023)\end{array}$ \\
\hline Family background & No & Yes & Yes & Yes & Yes \\
\hline Observations & 8380 & 8380 & 8380 & 8380 & 8380 \\
\hline $\mathrm{R}^{2}$ & 0.095 & 0.103 & 0.196 & 0.252 & 0.281 \\
\hline NLS: 1972 white grads & (1) & (2) & (3) & (4) & $(5)$ \\
\hline Female & $\begin{array}{l}-0.044 \\
(0.010)\end{array}$ & $\begin{array}{c}-0.024 \\
(0.0099)\end{array}$ & $\begin{array}{c}-0.0083 \\
(0.0091)\end{array}$ & $\begin{array}{c}-0.069 \\
(0.0093)\end{array}$ & $\begin{array}{c}-0.032 \\
(0.0094)\end{array}$ \\
\hline Composite score & & & $\begin{array}{c}0.187 \\
(0.0052)\end{array}$ & $\begin{array}{c}0.111 \\
(0.0062)\end{array}$ & $\begin{array}{c}0.078 \\
(0.0065)\end{array}$ \\
\hline HS rank percentile/100 & & & & $\begin{array}{c}0.439 \\
(0.021)\end{array}$ & $\begin{array}{c}0.400 \\
(0.020)\end{array}$ \\
\hline \multicolumn{6}{|l|}{ Courses (semesters) } \\
\hline Math & & & & & $\begin{array}{c}0.027 \\
(0.0028)\end{array}$ \\
\hline Science & & & & & $\begin{array}{c}0.022 \\
(0.0028)\end{array}$ \\
\hline Family background & No & Yes & Yes & Yes & Yes \\
\hline Observations & 7721 & 7721 & 7721 & 7721 & 7721 \\
\hline $\mathrm{R}^{2}$ & 0.002 & 0.121 & 0.246 & 0.287 & 0.312 \\
\hline
\end{tabular}

Sources: WLS (Wisconsin Longitudinal Survey 1957); NLS (National Longitudinal Survey 1972) restricted to white, non-Hispanics for comparability with the WLS.

Notes: The dependent variable is whether the senior received a 4-year college degree (B.A.) within seven to eight years of high school graduation. Composite score in 1972 is an average of the normalized math and reading scores for a comparison with IQ in 1957. HS rank percentile is the rank of the student in their senior class. Courses are measured in terms of semesters in the WLS and NLS. Family background variables include log (family income), and three dummies for mother's education. Missing data dummies are included for the three course variables, mother's education, and family income. 
Table 6: Determinants of College Completion among High School Graduates: 1972 and 1992

\begin{tabular}{|c|c|c|c|c|c|}
\hline NLS: 1972 graduates & (1) & (2) & (3) & (4) & (5) \\
\hline \multirow[t]{2}{*}{ Female } & -0.039 & -0.019 & 0.0089 & -0.051 & -0.025 \\
\hline & $(0.0092)$ & $(0.0088)$ & $(0.0083)$ & $(0.0085)$ & $(0.0085)$ \\
\hline \multirow[t]{2}{*}{ Math score } & & & 0.147 & 0.093 & 0.059 \\
\hline & & & $(0.0056)$ & $(0.0059)$ & $(0.0062)$ \\
\hline \multirow[t]{2}{*}{ Reading score } & & & 0.057 & 0.034 & 0.031 \\
\hline & & & $(0.0055)$ & $(0.0054)$ & $(0.0054)$ \\
\hline \multirow[t]{2}{*}{ HS rank percentile/100 } & & & & 0.410 & 0.383 \\
\hline & & & & $(0.018)$ & $(0.019)$ \\
\hline \multicolumn{6}{|l|}{ Courses (semesters) } \\
\hline \multirow[t]{2}{*}{ Math } & & & & & 0.025 \\
\hline & & & & & $(0.0026)$ \\
\hline \multirow[t]{2}{*}{ Science } & & & & & 0.025 \\
\hline & & & & & $(0.0020)$ \\
\hline Family background & No & Yes & Yes & Yes & Yes \\
\hline Observations & 9375 & 9375 & 9375 & 9375 & 9375 \\
\hline $\mathrm{R}^{2}$ & 0.002 & 0.120 & 0.251 & 0.289 & 0.311 \\
\hline NELS: 1992 graduates & (1) & (2) & (3) & (4) & (5) \\
\hline \multirow[t]{2}{*}{ Female } & 0.073 & 0.091 & 0.101 & 0.047 & 0.055 \\
\hline & $(0.012)$ & $(0.011)$ & $(0.010)$ & $(0.010)$ & $(0.010)$ \\
\hline \multirow[t]{2}{*}{ Math score } & & & 0.196 & 0.124 & 0.081 \\
\hline & & & $(0.0077)$ & $(0.0082)$ & $(0.0084)$ \\
\hline \multirow[t]{2}{*}{ Reading score } & & & 0.015 & -0.002 & 0.003 \\
\hline & & & $(0.0076)$ & $(0.0074)$ & $(0.0072)$ \\
\hline \multirow{2}{*}{ HS rank percentile/100 } & & & & 0.515 & 0.402 \\
\hline & & & & $(0.023)$ & $(0.024)$ \\
\hline \multicolumn{6}{|l|}{ Courses (Carnegie) } \\
\hline \multirow[t]{2}{*}{ Math } & & & & & 0.068 \\
\hline & & & & & $(0.0067)$ \\
\hline \multirow[t]{2}{*}{ Science } & & & & & 0.058 \\
\hline & & & & & $(0.0057)$ \\
\hline Family background & No & Yes & Yes & Yes & Yes \\
\hline Observations & 6671 & 6671 & 6671 & 6671 & 6671 \\
\hline $\mathrm{R}^{2}$ & 0.006 & 0.133 & 0.280 & 0.330 & 0.358 \\
\hline
\end{tabular}

Sources: NLS (National Longitudinal Survey 1972); NELS (National Educational Longitudinal Survey 1988).

Notes: The dependent variable is whether the senior received a 4-year college degree (B.A.) within seven to eight years of high school graduation. Math and Reading scores are normalized achievement test scores. HS rank percentile is a student's percentile rank in their senior class. Courses are measured in terms of semesters in the NLS and by Carnegie units (full-time annual equivalents) in the NELS. Family background variables include log (family income), four race/ethnicity dummies, and four dummies for mother's education. Missing data dummies are included for the three course variables, mother's education, and family income. 
Table 7: Determinants of College Completion among High School Graduates by Sex

\begin{tabular}{|c|c|c|c|c|}
\hline \multirow[t]{2}{*}{ NLS: 1972 graduates } & \multicolumn{2}{|c|}{ Males } & \multicolumn{2}{|c|}{ Females } \\
\hline & Coefficient & Means & Coefficient & Means \\
\hline $\begin{array}{l}\text { Dependent variable: } \\
\text { B.A. }=1\end{array}$ & & 0.297 & & 0.257 \\
\hline Math score & $\begin{array}{c}0.063 \\
(0.0091)\end{array}$ & 0.158 & $\begin{array}{c}0.054 \\
(0.085)\end{array}$ & -0.118 \\
\hline Reading score & $\begin{array}{c}0.022 \\
(0.0077)\end{array}$ & -0.0013 & $\begin{array}{c}0.041 \\
(0.0075)\end{array}$ & 0.034 \\
\hline HS rank percentile/100 & $\begin{array}{c}0.472 \\
(0.026)\end{array}$ & 0.489 & $\begin{array}{c}0.295 \\
(0.025)\end{array}$ & 0.604 \\
\hline \multicolumn{5}{|l|}{ Courses (semesters) } \\
\hline Math & $\begin{array}{c}0.020 \\
(0.0036)\end{array}$ & 4.13 & $\begin{array}{c}0.028 \\
(0.0037)\end{array}$ & 3.29 \\
\hline Science & $\begin{array}{c}0.016 \\
(0.0036)\end{array}$ & 3.78 & $\begin{array}{c}0.027 \\
(0.0037)\end{array}$ & 3.13 \\
\hline Family background & Yes & & Yes & \\
\hline Observations & 4506 & & 4869 & \\
\hline $\mathrm{R}^{2}$ & 0.323 & & 0.303 & \\
\hline \multirow[t]{2}{*}{ NELS: 1992 graduates } & \multicolumn{2}{|c|}{ Males } & \multicolumn{2}{|c|}{ Females } \\
\hline & Coefficient & Means & Coefficient & Means \\
\hline $\begin{array}{l}\text { Dependent variable: } \\
\text { B.A. }=1\end{array}$ & & 0.347 & & 0.420 \\
\hline Math score & $\begin{array}{c}0.086 \\
(0.012)\end{array}$ & 0.088 & $\begin{array}{c}0.068 \\
(0.012)\end{array}$ & -0.013 \\
\hline Reading score & $\begin{array}{l}-0.0013 \\
(0.0097)\end{array}$ & -0.061 & $\begin{array}{c}0.026 \\
(0.011)\end{array}$ & 0.142 \\
\hline HS rank percentile/100 & $\begin{array}{c}0.315 \\
(0.033)\end{array}$ & 0.520 & $\begin{array}{c}0.492 \\
(0.034)\end{array}$ & 0.616 \\
\hline \multicolumn{5}{|l|}{ Courses (Carnegie) } \\
\hline Math & $\begin{array}{c}0.063 \\
(0.0095)\end{array}$ & 3.27 & $\begin{array}{c}0.077 \\
(0.0094)\end{array}$ & 3.29 \\
\hline Science & $\begin{array}{c}0.060 \\
(0.0080)\end{array}$ & 3.06 & $\begin{array}{c}0.056 \\
(0.0081)\end{array}$ & 2.99 \\
\hline Family background & Yes & & Yes & \\
\hline $\begin{array}{l}\text { Observations } \\
\mathrm{R}^{2}\end{array}$ & $\begin{array}{c}3170 \\
0.340\end{array}$ & & $\begin{array}{l}3501 \\
0.380\end{array}$ & \\
\hline
\end{tabular}

Sources: NLS (National Longitudinal Survey 1972); NELS (National Educational Longitudinal Survey 1988).

Notes: The dependent variable is whether the senior received a 4-year college degree (B.A.) within seven to eight years of high school graduation. Variable definitions and family background controls are the same as in Table 6 . 
Table 8

College Completion Rates by Socio-Economic Status and Sex:

High School Graduating Classes of 1957, 1972, and 1992

A. Whites only

\begin{tabular}{|c|c|c|c|c|c|c|}
\hline \multirow{2}{*}{$\begin{array}{l}\text { SES } \\
\text { Quartiles }\end{array}$} & \multicolumn{2}{|c|}{ WLS 1957} & \multicolumn{2}{|c|}{ NLS 1972} & \multicolumn{2}{|c|}{ NELS 1992} \\
\hline & Males & Females & Males & Females & Males & Females \\
\hline 1 & 0.087 & 0.047 & 0.138 & 0.095 & 0.152 & 0.211 \\
\hline 2 & 0.142 & 0.064 & 0.205 & 0.195 & 0.259 & 0.386 \\
\hline 3 & 0.225 & 0.155 & 0.303 & 0.271 & 0.474 & 0.508 \\
\hline 4 & 0.429 & 0.339 & 0.556 & 0.551 & 0.706 & 0.770 \\
\hline Overall & 0.216 & 0.144 & 0.309 & 0.269 & 0.406 & 0.461 \\
\hline Observations & 4379 & 4609 & 4129 & 4448 & 2864 & 3203 \\
\hline
\end{tabular}

B. All

\begin{tabular}{lccccc}
\hline \hline \multirow{2}{*}{ QES } & \multicolumn{2}{c}{ NLS 1972 } & & \multicolumn{2}{c}{ NELS 1992 } \\
\cline { 2 - 3 } \cline { 5 - 6 } Quartiles & Males & Females & & Males & Females \\
\hline 1 & 0.127 & 0.094 & & 0.112 & 0.168 \\
2 & 0.184 & 0.181 & & 0.217 & 0.355 \\
3 & 0.277 & 0.252 & & 0.394 & 0.467 \\
4 & 0.536 & 0.521 & & 0.630 & 0.732 \\
& & & & & \\
Overall & 0.290 & 0.253 & & 0.344 & 0.424 \\
Observations & 5046 & 5549 & & 4097 & 4604 \\
\hline \hline
\end{tabular}

Sources: WLS (Wisconsin Longitudinal Survey 1957); NLS (National Longitudinal Survey 1972); and NELS (National Educational Longitudinal Survey 1988).

Notes: We use the raw SES composite measures available in the WLS, NLS and NELS. The SES composite in the WLS is based on four variables (father's schooling, mother's schooling, father's occupational prestige using the Duncan index; and parents' income). The SES composites in the NLS and NELS use five variables (the same four as the WLS plus mother's occupational prestige). The SES quartiles for each survey use high school graduates in the follow-up surveys (1964 wave for the WLS, 1979 wave for the NLS, and 2000 wave for the NELS) with non-missing SES data. The samples in Panel A are restricted to white, nonHispanics in the NLS and NELS for comparability with the WLS. 
Table 9

Role of Work Expectations on College Going and College Completion

\begin{tabular}{lcc}
\hline \hline Ages 14 to 17 in 1968 (15 to 18 in 1969) & Expectations in 1969, 1970 When 35 Years Old \\
\hline College Outcome $(\mathrm{N}=765)$ & Work & Not work \\
Fraction attending college (to 1985) & 0.545 & 0.368 \\
Fraction obtaining B.A. degree (to 1985) & 0.312 & 0.191
\end{tabular}

\begin{tabular}{lcc}
\hline Ages 14 to 18 in 1968 (15 to 19 in 1969) & Expectations in 1969, 1970 When 35 Years Old \\
\hline College Outcome $(\mathrm{N}=968)$ & Work & Not work \\
Fraction attending college (to 1985) & 0.553 & 0.366 \\
Fraction obtaining B.A. degree (to 1985) & 0.328 & 0.185 \\
\hline \hline
\end{tabular}

Sources and Notes: The 1968 National Longitudinal Survey of Young Women (NLS68) began with females who were 14 to 24 years old in 1968. The sample used here includes white females who were in the sample in the year the question on expectations was asked. The sample is also restricted to those interviewed in 1985 to allow sufficient time for college completion and because of significant attrition from the original sample. Those who listed "married, keeping house, raising a family" as the answer to "what will you be doing when you are 35 years old" are coded as not planning to be in the labor force at age 35. The mean education for the 14 to 16 year olds (white) in 1985 is 0.225 for B.A. degree and 0.441 for any college, somewhat less than the national aggregate. Weights are not used and do not materially affect the results for whites in the NLS68. The number of observations given is that for the college attendance results. 
Table 10

Evolution of College Women's Labor Market Activities by Cohort

\begin{tabular}{lccccc}
\hline \hline & & \multicolumn{3}{c}{ White, College Graduate Women, 30 to 34 Years Old } \\
\cline { 3 - 6 } Birth & Year & $\begin{array}{c}\text { Fraction } \\
\text { Employed }\end{array}$ & $\begin{array}{c}\text { Fraction } \\
\text { Employed Full- } \\
\text { Cohort }\end{array}$ & $\begin{array}{c}\text { Fraction with } \\
\text { time }\end{array}$ & $\begin{array}{c}\text { Fraction } \\
\text { Teachers of } \\
\text { those Employed }\end{array}$ \\
\hline $1906-10$ & 1940 & 0.484 & 0.333 & 0.422 & 0.555 \\
$1916-20$ & 1950 & 0.402 & 0.318 & 0.631 & 0.418 \\
$1926-30$ & 1960 & 0.387 & 0.255 & 0.734 & 0.471 \\
$1936-40$ & 1970 & 0.494 & 0.299 & 0.746 & 0.555 \\
$1946-50$ & 1980 & 0.695 & 0.546 & 0.597 & 0.363 \\
$1956-60$ & 1990 & 0.806 & 0.663 & 0.534 & 0.185 \\
$1966-70$ & 2000 & 0.801 & 0.651 & 0.530 & 0.184 \\
\hline \hline
\end{tabular}

Source: 1940 to 2000 Census IPUMS.

Notes: Samples consist of white, native-born college graduate women, 30 to 34 years old. Fraction with children consists of those with own-children living in household. 